Supporting Information (SI) for

\title{
Catechyl Lignin Extracted from Castor Seed Coats using Deep Eutectic Solvents: Characterization and Depolymerization
}

Shuizhong Wang, ${ }^{\dagger}$ Shihao Su, ${ }^{\dagger}$ Ling-Ping Xiao, ${ }^{*}$ Bo Wang ${ }^{\dagger}$ Run-Cang Sun ${ }^{\dagger}$ and Guoyong Song ${ }^{*}$

$\dagger$ Beijing Advanced Innovation Center for Tree Breeding by Molecular Design, Beijing Key Laboratory of Lignocellulosic Chemistry, Beijing Forestry University, No.35 Tsinghua East Road, Beijing, 100083, P.R. China

†Center for Lignocellulose Chemistry and Biomaterials, Dalian Polytechnic University, No.1 Qinggongyuan, Dalian, Liaoning, 116034, P.R. China

${ }^{*}$ Corresponding authors.

E-mail: G.S: songg@bjfu.edu.cn; L.-P.X: 1pxiao@dlpu.edu.cn

\section{Summary of Content:}

Number of pages: 35

Number of Tables: 9

Number of Figures: 14

\section{Table of contents}

1. General information

2. The Preparation of deep eutectic solvents (DESs)

3. Isolation of castor seed coats lignin samples by various methods

4. Structural characterization of C-lignin samples

5. The comparison of $\mathrm{ChCl} / \mathrm{LA}$ DES and other isolated methods

6. Catalytic hydrogenolysis of castor seed coats lignin

7. Synthesis of propanolcatechol $\mathbf{1}$ and propylcatechol $\mathbf{2}$ and their silylated derivatives

8. Representative GC calibration curves and mass spectra, and NMR spectra $\left({ }^{1} \mathrm{H},{ }^{13} \mathrm{C}\right)$ of standard compounds

9. References 


\section{General information}

All commercially available chemical reagents were used without further purification. $\mathrm{Pd} / \mathrm{C}(\mathrm{Pd}$ content: $5 \mathrm{wt} \%)$ and (Ru content: $5 \mathrm{wt} \%)$ were purchased from Energy Chemical. Cellulase and xylanase are purchased from Shandong Longcote Enzyme Preparation Co., Ltd.

\section{Klason lignin, carbohydrate and ash analysis}

The content of Klason lignin and carbohydrate in castor seed coats was measured according to NREL/TP-510-42618 protocol. ${ }^{1}$ In a typical step, the ball milled castor seed coats or lignin (300 $\mathrm{mg}$ ) were weighed into a pressure tube, and $3 \mathrm{~mL}$ of $72 \%(\mathrm{w} / \mathrm{w})$ sulfuric acid was added. After being mixed, the tube was placed into a water bath at $30^{\circ} \mathrm{C}$ and incubated the sample for $60 \mathrm{~min}$ under manual stirring. When hydrolysis was completed, the tube was removed from the water bath, and the $72 \%$ sulphuric acid was diluted to $4 \%$ via adding deionized water $(84 \mathrm{~mL})$. After that, the tube was sealed and placed into high pressure sterilizer at $121{ }^{\circ} \mathrm{C}$ for $60 \mathrm{~min}$. When the reactor was cooled to ambient temperature, the solid and liquid were separated by filter crucible (filter diameter 4-7 um). The solid residue was dried at $110{ }^{\circ} \mathrm{C}$ to obtain Klason lignin. Subsequently, the mother liquid was diluted 50 times using the deionized water, filtered by 0.22 um syringe filter, and measured by HPAEC to obtain contents of carbohydrates.

The ash in castor seed coats was analyzed according to NREL/TP-510-42622 protocol described previously. ${ }^{2}$ In short, the dried sample (mass, M1) was placed into quartz tube and treated under $575{ }^{\circ} \mathrm{C}$ for $4 \mathrm{~h}$ under air atmosphere, after quartz tube cool to room temperature, the remaining solid was treated again under same conditions until the content of ash is constant weight (mass, M2). The ash content was obtained according to M2/M1 x 100\%.

\section{GPC analyses}

The average molecular weight of lignin samples (THF solution, $c a .2 \mathrm{mg} \mathrm{mL}^{-1}$ ) was performed on Shimadzu LC-20AD equipped with a PL-gel $10 \mu \mathrm{m}$ Mixed-B $7.5 \mathrm{~mm}$ I.D. column (mixed) and UV detection detector $(254 \mathrm{~nm})$ at $50{ }^{\circ} \mathrm{C}$, using THF as the solvent $\left(1 \mathrm{~mL} \mathrm{~min}^{-1}\right)$, which was calibrated with polystyrene standards (peaks average molecular weights of 96, 500, 1,320, 9,200, 66,000 $\mathrm{g} \mathrm{mol}^{-1}$, Polymer Laboratories Ltd.). The procedure of lignin acetylation: lignin sample (10 mg) was treated with a 1:1 mixture of acetic anhydride/pyridine $(1.0 \mathrm{~mL})$ at room temperature for $72 \mathrm{~h}$. The acetylated products were dissolved in THF (ca. $\left.2 \mathrm{mg} \mathrm{mL}^{-1}\right)$ and filtered with a PTFE filter $(0.45 \mu \mathrm{m})$ prior to injection. For lignin oily product: after removal of 
the methanol, the residue was dissolved in THF ( $\left.c a .2 \mathrm{mg} \mathrm{mL}^{-1}\right)$ and filtered with a PTFE filter $(0.45 \mu \mathrm{m})$ prior to injection.

\section{NMR analysis}

The NMR spectra were acquired on a Bruker Avance $400 \mathrm{MHz}$ spectrometer.

2D HSQC NMR analysis: lignin samples or lignin oil $(50 \mathrm{mg})$ were dissolved in deuterated dimethyl sulfoxide (DMSO- $d_{6}, 0.5 \mathrm{~mL}$ ). The central solvent peak at $\delta_{\mathrm{C}} / \delta_{\mathrm{H}} 39.5 / 2.49 \mathrm{ppm}$ was used as an internal reference. HSQC cross-peaks assigned by combining the results and comparing them with the literatures. ${ }^{3}$ A semi-quantitative analysis of the HSQC cross-peak intensities were performed in the side-chain region, the ratio of $\mathrm{A}$ and $\mathrm{B}$ were estimated from the corresponding integrations of benzodioxane $(\mathrm{A}, \mathrm{A} \alpha)$, resinol $(\mathrm{B}, \mathrm{B} \alpha)$, and cinnamyl alcohol end-unit $(\mathrm{C}, \mathrm{C} \alpha)$. Volume integration of peaks in HSQC plots was accomplished using Bruker's TopSpin 3.0 software.

Quantitative ${ }^{13} \mathbf{C}$ NMR analysis: The samples were prepared according to previous report. ${ }^{3}$ ChCL/LA-extracted C-lignin (100 mg) were weighed accurately and dissolved in internal standard [1 mL, (IS, 1,3,5-trioxane, DMSO- $\left.d_{6} 3.12 \mathrm{mg} \mathrm{mL}^{-1}\right)$ ] solution, in which ChCl/LAextracted C-lignin was also $100 \mathrm{mg} \mathrm{mL}^{-1}$. And then, relaxation reagent chromium(III) acetylacetonate $\left[\mathrm{Cr}(\mathrm{acac})_{3}, \mathrm{ca} .2 \mathrm{mg}\right.$ ] was added to the samples to facilitate the relaxation of the magnetization.

\section{Lignin oily product analysis}

GC-MS analysis of lignin oily products was performed on Shimadu GCMS-QP2010SE equipped with a HP-5 MS (30 m x $250 \mathrm{~mm}$ x 0.25, Agilent) capillary column and a mass spectroscopy detector. GC analysis of lignin oily products was performed on Shimadu GC-2010 equipped with a HP-5 (30 m x $250 \mathrm{~mm}$ x 0.25, Agilent) capillary column and FID. Lignin oily product dissolved in anhydrous tetrahydrofuran (THF) with an external standard (tetradecane) was silylated with excess N,O-bis(trimethylsilyl)trifluoroacetamide (BSTFA) at $65{ }^{\circ} \mathrm{C}$ for $1 \mathrm{~h}$ under $\mathrm{N}_{2}{ }^{4}$ After treatment, the mixture was subjected to GC-MS and GC-FID for analysis after filtration with a PTFE filter $(0.45 \mu \mathrm{m})$. The identification and quantification of lignin monomers in the oily product were assessed by comparison with authentic samples. 


\section{The preparation of deep eutectic solvents (DESs)}

In this study, a series of deep eutectic solvents (DESs), which were composed by cholinium chloride $(\mathrm{ChCl})$ as HBA with different HBDs, were prepared according to previous reports. ${ }^{5,6}$ In a typical step, choline chloride $(\mathrm{ChCl} / \mathrm{Cl})$ and lactic acid (LA) were used as starting materials with a mole ratio of $1: 2$ to obtain $\mathrm{ChCl} / \mathrm{LA}$ DES. The mixture was placed into sealed bottle to react with magnetic stirring $(500 \mathrm{rpm})$ at $65{ }^{\circ} \mathrm{C}$ in oil-bath until a transparent and homogeneous liquid was formed. The remaining DESs were obtained according to above step at desired reaction temperature (Table S1). And the acquired DESs were stored in desiccator for further utilization.

Subsequently, solvatochromic parameters $\left(\alpha, \beta\right.$ and $\left.\pi^{*}\right)$ of seven DESs were measured according to previous reports, ${ }^{7-9}$ the detailed results were showed at Table S1.

Table S1. The solvatochromic parameters and formed temperature of DESs.

\begin{tabular}{|c|c|c|c|c|c|c|}
\hline Entry & DESs & $\pi^{*}$ & $\alpha$ & $\beta$ & $\begin{array}{l}\text { HBA/HBD } \\
\text { (molar ratio) }\end{array}$ & $\begin{array}{l}\text { DES formation } \\
\text { temperature }(\mathrm{K})\end{array}$ \\
\hline 1 & $\mathrm{ChCl} /$ lactic acid & 1.023 & 1.331 & 0.513 & $1: 2$ & 338.15 \\
\hline 2 & $\mathrm{ChCl} /$ formic acid & 1.392 & 1.782 & -1.620 & $1: 2$ & 338.15 \\
\hline 3 & $\mathrm{ChCl} /$ acetic acid & 0.888 & 1.166 & 0.689 & $1: 2$ & 333.15 \\
\hline 4 & $\mathrm{ChCl} /$ oxalic acid ${ }^{\text {a }}$ & - & - & - & $1: 1$ & 463.15 \\
\hline 5 & $\mathrm{ChCl} /$ malonic acid & 1.409 & 1.803 & 0.103 & $1: 1$ & 338.15 \\
\hline 6 & $\begin{array}{l}\mathrm{ChCl} / \text { ethylene } \\
\text { glycol }\end{array}$ & 0.726 & 0.967 & 1.067 & $1: 2$ & 338.15 \\
\hline 7 & $\mathrm{ChCl} /$ glycerol & 0.673 & 0.902 & 1.102 & $1: 2$ & 338.15 \\
\hline
\end{tabular}

\footnotetext{
${ }^{\mathrm{a}}$ when oxalic acid $(\mathrm{OA})$ was used as $\mathrm{HBD}$, the formed $\mathrm{ChCl} / \mathrm{OA} \mathrm{DES}$ occurred partial solid at room temperature $\left(10^{\circ} \mathrm{C}\right)$, thus the parameters of $\mathrm{ChCl} / \mathrm{OA}$ DES could not be given.
} 


\section{Isolation of castor seed coats lignin samples by various methods}

Castor seed coats were obtained from Shandong, China. The dried castor seed coats raw materials were crushed into pieces (20-40 mesh), and then successively extracted with acetone (8 h) and hot water (5 h) to remove some extractives (ca. 15\%) using a Soxhlet instrument (Figure S1), ${ }^{10}$ then the castor seed coats were milled using a planetary ball-mill (Fritsch GmbH, Germany) for 5 h. Finally, the castor seed coats after extraction (20-40 mesh) and ball milled castor seed coats were stored in desiccator for further utilization.

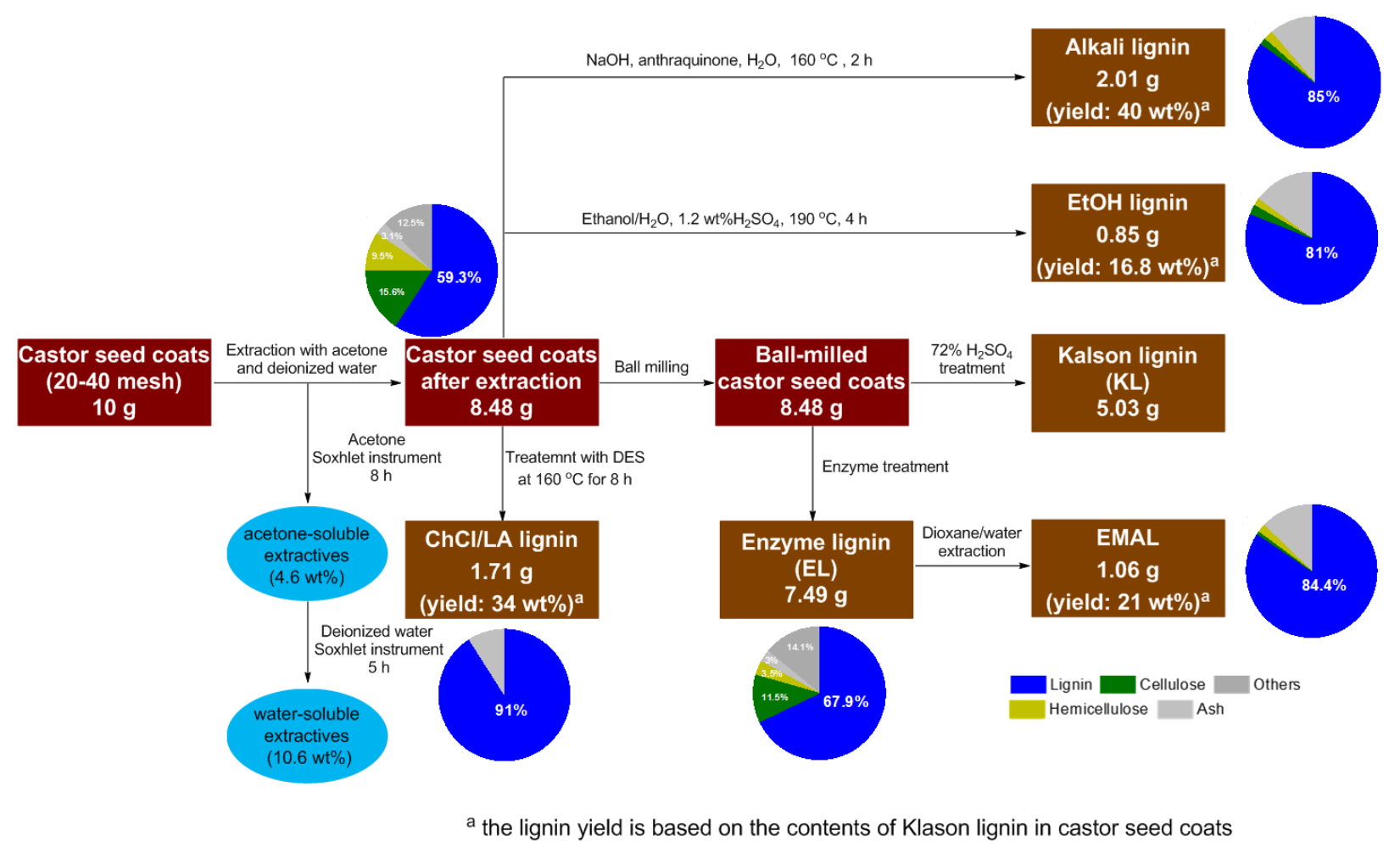

Figure S1. The flowchart of isolation of different lignin samples from castor seed coats.

\subsection{Treatment castor seed coats with different DESs}

For DESs pretreatment, castor seed coats after extraction (20-40 mesh, $3 \mathrm{~g}$ ) and DES (30 g) were loaded in a $100 \mathrm{~mL}$ reactor, which was heated to desired reaction temperature for a certain time with magnetic stirring (500 rpm). At the end of pretreatment, the reactor was cooled and the thick reaction mixture was diluted with ethanol $(15 \mathrm{~mL})$ followed by vacuum filtration. The solid residue was washed with $\mathrm{EtOH}$ and then dried at $35^{\circ} \mathrm{C}$. The above filtrates were collected and evaporated to remove $\mathrm{EtOH}$, then the concentrated filtrates were added dropwise to a $400 \mathrm{~L}$ of $\mathrm{HCl}$ aqueous solution $(\mathrm{pH}=2.0)$ to form a precipitate, which was on the treatment of 
centrifugation, washing with ethanol/water (v/v, 1:9) and freeze-drying to afford DES-extracted lignin for further utilization.

For reusability of $\mathrm{ChCl} / \mathrm{LA} \mathrm{DES}$, the spent $\mathrm{ChCl} / \mathrm{LA} \mathrm{DES}$ could be recovered with a high recovery rate $(92 \%)$ by the removal of $\mathrm{EtOH}$ and water, the recycled $\mathrm{ChCl} / \mathrm{LA} \mathrm{DES}$ was directly used to treat castor seed coats under same reaction condition.

For successive treatment of castor seed coats, the treated seed coats was dired at $60{ }^{\circ} \mathrm{C}$ in a oven and was then treated with fresh $\mathrm{ChCl} / \mathrm{LA}$ DES to extraction $\mathrm{C}$-lignin.

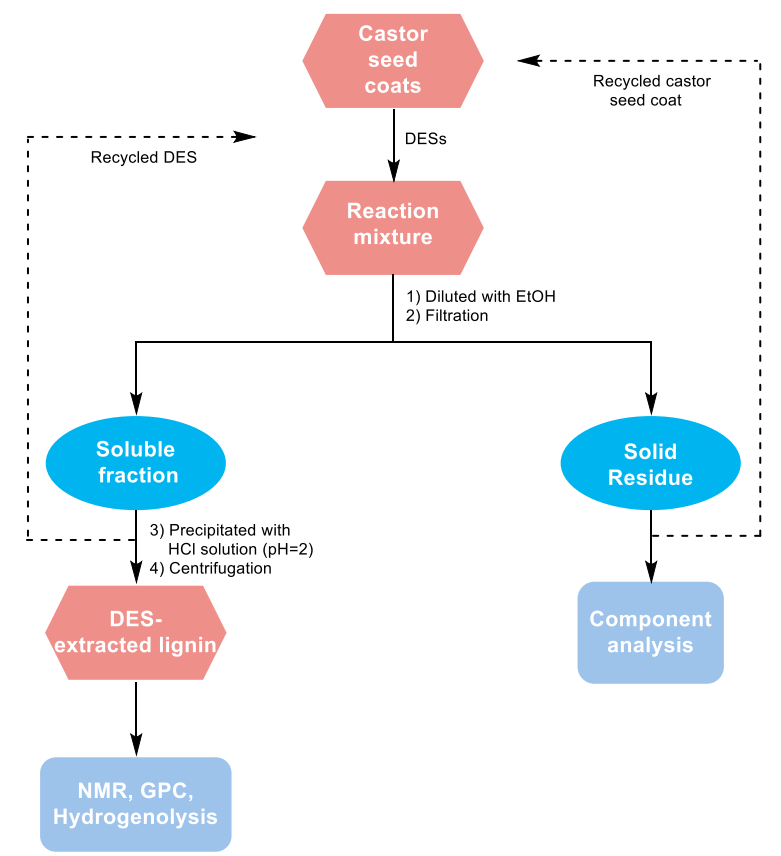

Figure S2. The post-processing flowchart of treatment of castor seed coats with DESs.

\subsection{Enzyme treatment of castor seed coats}

Enzyme treatment of ball milled castor seed coats were performed according to the following procedure. The ball milled castor seed coats $(10 \mathrm{~g})$ were treated with cellulase $(200000 \mu / \mathrm{g})$ and xylanase $(290000 \mu / \mathrm{g})$ with a ratio of $0.75 \mathrm{~g} / \mathrm{g}$ wood, respectively, in citrate buffer $(200 \mathrm{~mL}, 50$ $\mathrm{mM}, \mathrm{pH} 4.8$ ) in an orbital water bath shaker at $50{ }^{\circ} \mathrm{C}$ for $48 \mathrm{~h}$. After enzymatic hydrolysis, the insoluble residue was collected by centrifugation at $4000 \mathrm{rpm}$, which was treated with cellulase and xylanase again under same conditions. The insoluble solid was collected, washed with deionized water, and freeze-dried to afford enzymatic lignin $(8.83 \mathrm{~g})$. 


\subsection{Isolation of castor seed coats EMAL}

EMAL was isolated from castor seed coats according to the procedure developed by $\mathrm{Wu}$ and Argyropoulos. ${ }^{11}$ The suspension of enzymatic lignin $(8.83 \mathrm{~g})$ in an acidic $\left([\mathrm{HCl}]=0.01 \mathrm{~mol} \mathrm{~L}^{-1}\right)$ mixture of dioxane/water $(85: 15, \mathrm{v} / \mathrm{v})$ with a solid-to-liquid ratio of $1: 15\left(\mathrm{~g} \mathrm{~mL}^{-1}\right)$ was refluxed (azeotrope, $86^{\circ} \mathrm{C}$ ) under nitrogen for $4 \mathrm{~h}$. The solid was collected by centrifugation (4000 rpm) and washed with dioxane/water $(85: 15, \mathrm{v} / \mathrm{v})$. The combined supernatant was neutralized with sodium bicarbonate, followed by evaporation to afford a thick solution. This solution was added dropwise to a $1 \mathrm{~L}$ of $\mathrm{HCl}$ aqueous solution $(\mathrm{pH}=2.0)$ to form a precipitate, which was allowed to equilibrate at $4{ }^{\circ} \mathrm{C}$ overnight. The EMAL could be obtained by centrifugation, washing with $\mathrm{HCl}$ aqueous solution $(\mathrm{pH}=2.0)$, and freeze-drying $(1.2 \mathrm{~g}$, yield, $21 \%)$.

\subsection{Isolation of castor seed coats ethanol organosolv lignin (EtOH lignin)}

The castor seed coats after extraction $(10 \mathrm{~g})$ were treated with aqueous ethanol $(35 / 65, \mathrm{v} / \mathrm{v})$, and $1.2 \mathrm{wt} \%(\mathrm{w} / \mathrm{w})$ (based on raw material mass) sulfuric acid as a catalyst at $190{ }^{\circ} \mathrm{C}$ for $4 \mathrm{~h}$ in reactor, in which the solid to liquid ratio was 1:10, following the method described in previous report with a minor improvement. ${ }^{12}$ After treatment, the mixture was filtered and washed with ethanol $(100 \mathrm{~mL})$. Then the acquired liquid was concentrated to afford a thick solution. This solution was added dropwise to a $1 \mathrm{~L}$ of $\mathrm{HCl}$ aqueous solution $(\mathrm{pH}=2.0)$ to form a precipitate, which was allowed to equilibrate at $4{ }^{\circ} \mathrm{C}$ overnight. The EtOH lignin could be obtained by centrifugation, washing with $\mathrm{HCl}$ aqueous solution $(\mathrm{pH}=2.0)$, and freeze-drying (1.0 g, yield, $16.8 \%)$.

\subsection{Isolation of castor seed coats alkali lignin}

Alkali lignin was isolated from castor seed coats according to typical alkaline delignification process. ${ }^{13}$ The mixtures of castor seed coats $(5.0 \mathrm{~g})$, sodium hydroxide (16 wt\%, $0.8 \mathrm{~g}$ ), anthraquinone (AQ, $0.5 \mathrm{wt} \%, 0.025 \mathrm{~g})$ and deionized water $(30 \mathrm{~mL})$ was placed into reactor and cooked at $160{ }^{\circ} \mathrm{C}$ for $2 \mathrm{~h}$. After cooking, the black liquid was collected by filtration and adjusted the acidity of solution $(\mathrm{pH}=2)$ to generate a precipitate, which was allowed to equilibrate at $4{ }^{\circ} \mathrm{C}$ overnight. The alkali lignin could be obtained by centrifugation, washing with $\mathrm{HCl}$ aqueous solution $(\mathrm{pH}=2.0)$, and freeze-drying $(1.2 \mathrm{~g}$, yield, $40 \%)$. 


\section{Structural characterization of $\mathrm{C}$-lignin samples}

Table S2. The yields and chemical compositional analysis of different lignin samples isolated from castor seed coats.

\begin{tabular}{ccccccc}
\hline Entry & Samples & $\begin{array}{c}\text { Yield of lignin } \\
(\mathrm{wt} \%)^{\mathrm{a}}\end{array}$ & $\begin{array}{c}\text { Klason lignin } \\
(\mathrm{wt} \%)\end{array}$ & $\begin{array}{c}\text { Glucose } \\
(\mathrm{wt} \%)\end{array}$ & $\begin{array}{c}\text { Xylose } \\
(\mathrm{wt} \%)\end{array}$ & Ash (wt\%) \\
\hline 1 & $\begin{array}{c}\text { Castor seed } \\
\text { coats }\end{array}$ & - & 59.3 & 15.6 & 9.5 & 3.1 \\
2 & $\begin{array}{c}\text { Enzymatic } \\
\text { lignin }\end{array}$ & 100 & 67.9 & 11.5 & 3.5 & 3.0 \\
3 & EMAL & 21.0 & 84.4 & 0.6 & 2.1 & -- \\
4 & EtOH-lignin & 16.8 & 81.0 & 2.3 & 1.8 & -- \\
5 & Alkali lignin & 40.0 & 85.0 & 1.5 & 2.3 & -- \\
\hline
\end{tabular}

\footnotetext{
${ }^{\mathrm{a}}$ based on the content of Klason lignin in castor seed coats.
} 
Table S3. The distributions of lignin yield, Klason lignin contents and chemical compositional analysis of residue after different DESs treatment. ${ }^{\mathrm{a}}$

\begin{tabular}{|c|c|c|c|c|c|c|c|}
\hline \multirow{2}{*}{ Entry } & \multirow{2}{*}{ DESs } & \multirow{2}{*}{$\begin{array}{l}\text { Yield of } \\
\text { lignin } \\
(\mathrm{wt} \%)^{\mathrm{b}}\end{array}$} & \multirow{2}{*}{$\begin{array}{l}\text { Klason } \\
\text { lignin } \\
(\mathrm{wt} \%)\end{array}$} & \multirow{2}{*}{$\begin{array}{l}\text { Residue } \\
(\mathrm{wt} \%)^{\mathrm{c}}\end{array}$} & \multicolumn{3}{|c|}{ Chemical component analysis of residue } \\
\hline & & & & & $\begin{array}{l}\text { Klason } \\
\text { lignin } \\
(\mathrm{wt} \%)\end{array}$ & $\begin{array}{l}\text { Glucose } \\
\text { (wt } \%)\end{array}$ & $\begin{array}{l}\text { Xylose } \\
\text { (wt\%) }\end{array}$ \\
\hline 1 & $\mathrm{ChCl} /$ lactic acid (LA) & 34 & 91 & 70 & 54.2 & 18.9 & 5.6 \\
\hline 2 & $\begin{array}{l}\mathrm{ChCl} / \text { lactic acid (LA) } \\
\left(2^{\text {nd }} \text { extraction on }\right. \\
\text { coats })\end{array}$ & 6 & 88 & - & - & - & - \\
\hline 3 & $\begin{array}{c}\mathrm{ChCl} / \text { lactic acid (LA) } \\
\left(3^{\text {rd }} \text { extraction on }\right. \\
\text { coats })\end{array}$ & 1 & 87 & - & - & - & - \\
\hline 4 & $\begin{array}{c}\mathrm{ChCl} / \text { formic acid } \\
\text { (FA) }\end{array}$ & 33 & 85 & 74 & 52.0 & 20.6 & 5.9 \\
\hline 5 & $\mathrm{ChCl} /$ acetic acid (AA) & 31 & 88 & 75 & 53.1 & 19.5 & 7.7 \\
\hline 6 & $\begin{array}{c}\mathrm{ChCl} \text { /oxalic acid } \\
\text { (OA) }\end{array}$ & 9 & 88 & 83 & 62.0 & 16.2 & 9.0 \\
\hline 7 & $\begin{array}{c}\mathrm{ChCl} / \text { malonic acid } \\
\text { (MA) }\end{array}$ & 3 & 86 & 99 & 57.0 & 15.8 & 8.0 \\
\hline 8 & $\begin{array}{l}\mathrm{ChCl} / \text { ethylene glycol } \\
\text { (EG) }\end{array}$ & 8 & 86 & 95 & 57.0 & 14.9 & 7.5 \\
\hline 9 & $\begin{array}{l}\mathrm{ChCl} / \text { glycerol } \\
\text { (Gly) }\end{array}$ & 4 & 87 & 97 & 58.2 & 15.3 & 7.9 \\
\hline
\end{tabular}

${ }^{\mathrm{a}}$ Reaction condition: castor seed coats $(3.0 \mathrm{~g})$, DES $(30.0 \mathrm{~g}), 160{ }^{\circ} \mathrm{C}, 8 \mathrm{~h}$; ${ }^{\mathrm{b}}$ based on the content of Klason lignin in castor seed coats; ${ }^{\mathrm{c}}$ residue was obtained after DESs treatment of castor seed coats. 


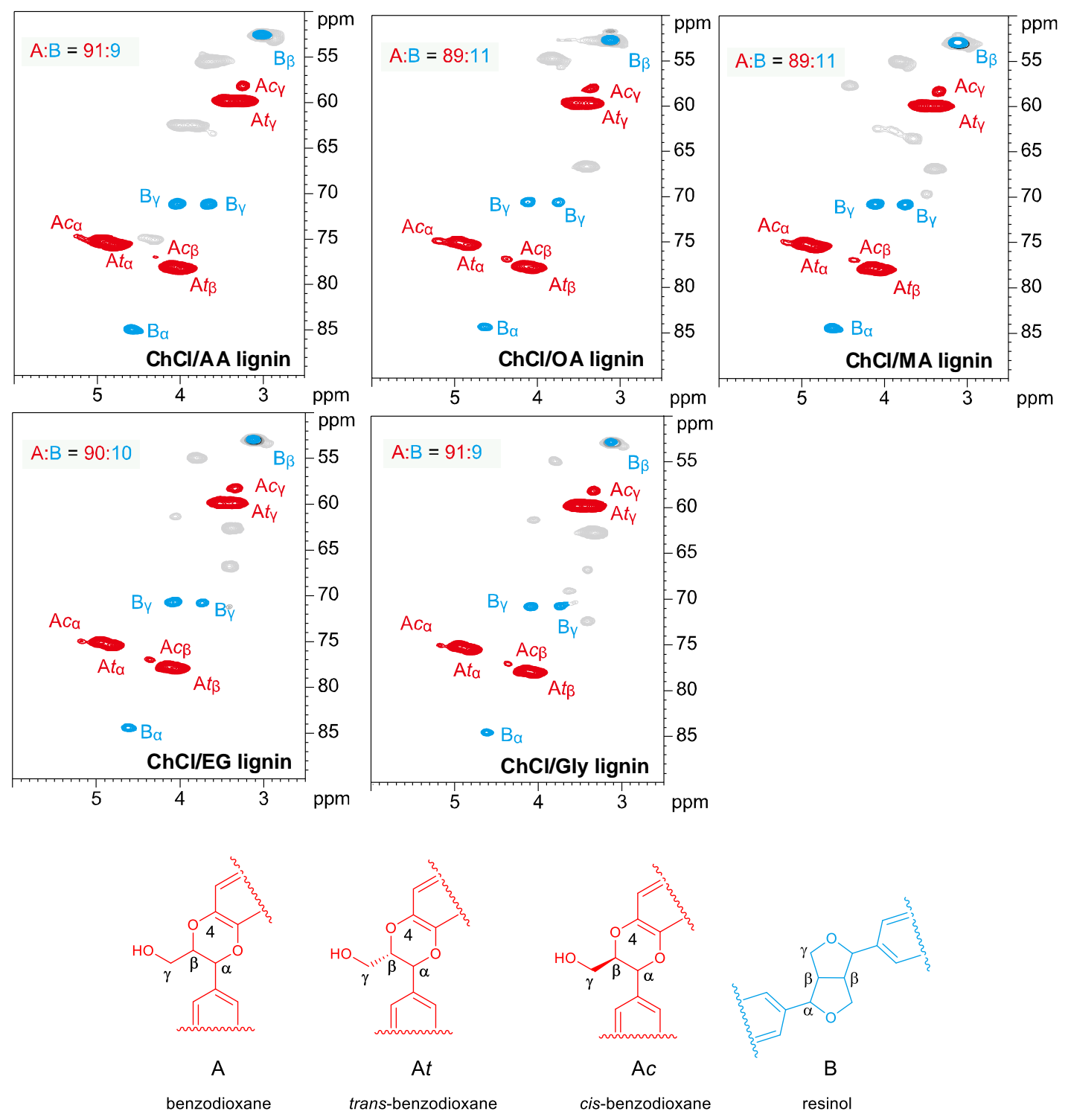

Figure S3. Expanded aliphatic side-chain regions of 2D HSQC NMR spectra of lignin samples isolated from castor seed coats by different DESs treatment. 

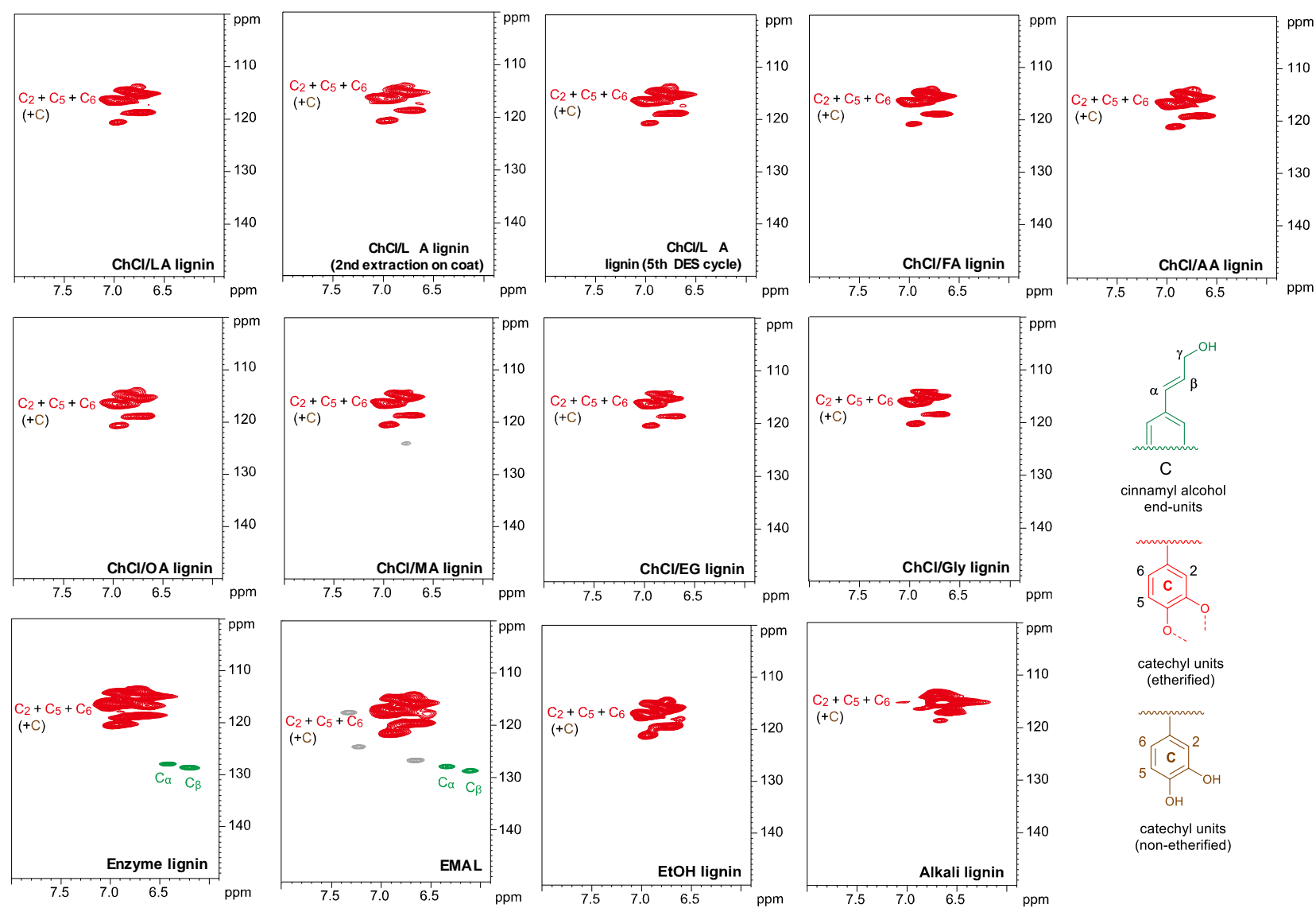

cinnamyl alcohol

end-units

62

${ }_{5} \mathrm{c}$

o.

atechyl units (etherified)

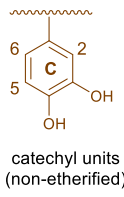

Figure S4. Expanded aromatic regions of 2D HSQC NMR spectra of lignin samples isolated from castor seed coats by different isolation methods. 
Table S4. NMR data for the signal assignments in castor lignin samples and lignin oily products in DMSO- $d_{6}$.

\begin{tabular}{|c|c|c|}
\hline Lable & $\delta_{\mathrm{C}} / \delta_{\mathrm{H}}(\mathrm{ppm})$ & Assignment \\
\hline $\mathrm{A} t_{\alpha}$ & $75.4 / 4.83$ & $\mathrm{C}_{\alpha}-\mathrm{H}_{\alpha}$ in trans-benzodioxane substructures (A) \\
\hline $\mathrm{A} t_{\beta}$ & $77.9-4.06$ & $\mathrm{C}_{\beta}-\mathrm{H}_{\beta}$ in trans-benzodioxane substructures (A) \\
\hline $\mathrm{A} t_{\gamma}$ & $59.9 / 3.34-3.55$ & $\mathrm{C}_{\gamma}-\mathrm{H}_{\gamma}$ in trans-benzodioxane substructures (A) \\
\hline $\mathrm{A} c_{\alpha}$ & $74.8-5.18$ & $\mathrm{C}_{\alpha}-\mathrm{H}_{\alpha}$ in cis-benzodioxane substructures (A) \\
\hline $\mathrm{A} c_{\beta}$ & $76.9-4.38$ & $\mathrm{C}_{\beta}-\mathrm{H}_{\beta}$ in cis-benzodioxane substructures (A) \\
\hline $\mathrm{A} c_{\gamma}$ & $58.4-3.35$ & $\mathrm{C}_{\gamma}-\mathrm{H}_{\gamma}$ in cis-benzodioxane substructures (A) \\
\hline $\mathrm{B}_{\alpha}$ & $84.5 / 4.62$ & $\mathrm{C}_{\alpha}-\mathrm{H}_{\alpha}$ in $\beta-\beta$ resinol substructures (B) \\
\hline $\mathrm{B}_{\beta}$ & $53.4 / 3.04$ & $\mathrm{C}_{\beta}-\mathrm{H}_{\beta}$ in $\beta-\beta$ resinol substructures (B) \\
\hline $\mathrm{B}_{\gamma}$ & $70.7 / 3.74-4.09$ & $\mathrm{C}_{\gamma}-\mathrm{H}_{\gamma}$ in $\beta-\beta$ resinol substructures (B) \\
\hline $\mathrm{C}_{\alpha}$ & $127.9 / 6.42$ & $\mathrm{C}_{\alpha}-\mathrm{H}_{\alpha}$ in cinnamyl alcohol end-units $(\mathrm{C})$ \\
\hline $\mathrm{C}_{\beta}$ & $128.7 / 6.20$ & $\mathrm{C}_{\beta}-\mathrm{H}_{\beta}$ in cinnamyl alcohol end-units $(\mathrm{C})$ \\
\hline $\mathrm{C}_{\gamma}$ & $61.4 / 4.10$ & $\mathrm{C}_{\gamma}-\mathrm{H}_{\gamma}$ in cinnamyl alcohol end-units $(\mathrm{C})$ \\
\hline $\mathrm{C}_{2}, \mathrm{C}_{5}, \mathrm{C}_{6}$ & $\begin{array}{l}115.8 / 6.77,116.5 / 6.95 \\
118.6 / 6.70,120.4 / 6.95\end{array}$ & $\mathrm{C}_{2}-\mathrm{H}_{2}, \mathrm{C}_{5}-\mathrm{H}_{5}, \mathrm{C}_{6}-\mathrm{H}_{6}$ in catechol units $(\mathrm{C})$ \\
\hline $\mathbf{1}(\alpha)$ & $32.0 / 2.77$ & $\mathrm{C}_{\alpha}-\mathrm{H}_{\alpha}$ in compound $\mathbf{1}$ \\
\hline $\mathbf{1}(\beta)$ & $33.5 / 1.82$ & $\mathrm{C}_{\beta}-\mathrm{H}_{\beta}$ in compound $\mathbf{1}$ \\
\hline $\mathbf{1}(\gamma)$ & $62.4 / 3.49$ & $\mathrm{C}_{\gamma}-\mathrm{H}_{\gamma}$ in compound $\mathbf{1}$ \\
\hline $2(\alpha)$ & $38.2 / 2.61$ & $\mathrm{C}_{\alpha}-\mathrm{H}_{\alpha}$ in compound 2 \\
\hline $2(\beta)$ & $24.1 / 1.64$ & $\mathrm{C}_{\beta}-\mathrm{H}_{\beta}$ in compound 2 \\
\hline $2(\gamma)$ & $13.7 / 0.94$ & $\mathrm{C}_{\gamma}-\mathrm{H}_{\gamma}$ in compound 2 \\
\hline
\end{tabular}


The weight percentage of $\mathrm{C}$-lignin in $\mathrm{ChCl} / \mathrm{LA}$ lignin was calculated based on the results of quantitative ${ }^{13} \mathrm{C}$ NMR. The peak integral of $\mathrm{C}_{\alpha}(2.68)$ is larger than that of $\mathrm{C}_{\beta}(1.79)$ resulting from peak overlap of unknown fraction in lignin sample at $\mathrm{C}_{\alpha}$, as a result, the peak integral of $\mathrm{C}_{\beta}$ was chosen for the quantification. The detailed calculation was shown at equations (1-3) and Table S5.

Table S5. Quantitative ${ }^{13} \mathrm{C}$ NMR analysis of C-lignin content in the ChCl/LA lignin.

\begin{tabular}{cc}
\hline $\mathrm{C}_{\mathrm{IS}}\left(\mu \mathrm{mol} \mathrm{mL}^{-1}\right)$ & 34.64 \\
$\mathrm{~A}_{\mathrm{IS}}$ & 1 \\
$\mathrm{~A}_{\mathrm{C} \beta}$ & 1.79 \\
$\mathrm{C}_{\mathrm{C} \beta}\left(\mu \mathrm{mol} \mathrm{mL}^{-1}\right)$ & 187.1 \\
$\rho_{\mathrm{ChC} / \mathrm{LA} \text { lignin }}\left(\mathrm{mg} \mathrm{mmol}^{-1}\right)$ & 100 \\
$\mathrm{Y}_{\mathrm{CA}}\left(\mu \mathrm{mol} \mathrm{mg}^{-1}\right)$ & 1.871 \\
$\mathrm{Mw}_{\mathrm{CA}}\left(\mathrm{mg} \mathrm{mmol}{ }^{-1}\right)$ & 166.18 \\
$\mathrm{~W}_{\mathrm{ChCl/LA} \mathrm{lignin}}$ & $31 \%$ \\
\hline
\end{tabular}

$$
\begin{aligned}
& C_{c \beta}=\frac{C_{I S} \times 3}{A_{I S}} \times A_{c \beta}
\end{aligned}
$$

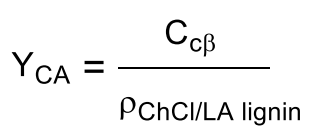

$$
\begin{aligned}
& W_{\text {ChCILA lignin }}=Y_{C A} \times M_{W C A} \times 100 \%
\end{aligned}
$$

In Table $\mathrm{S} 5$ and above equations, $\mathrm{C}_{\mathrm{IS}}\left(\mathrm{mmol} \mathrm{mL}^{-1}\right)$ is the molar concentration of internal standard (IS, 1,3,5-trioxane); $A_{I S}$ is the peak integral of IS in the quantitative ${ }^{13} \mathrm{C}$ NMR spectrum; $A_{C \beta}$ is the peak integral of $\mathrm{C}_{\beta}$ in the quantitative ${ }^{13} \mathrm{C}$ NMR spectrum; $\mathrm{C}_{\mathrm{C} \beta}\left(\mathrm{mmol} \mathrm{mL}^{-1}\right)$ is the molar

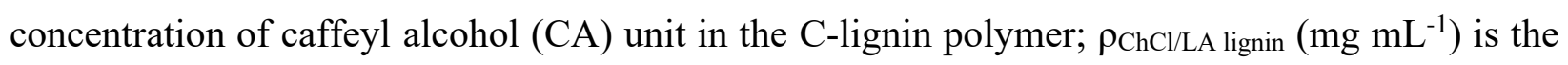
mass concentration of $\mathrm{ChCl} / \mathrm{LA}$ lignin sample; $\mathrm{Y}_{\mathrm{CA}}\left(\mathrm{mmol} \mathrm{mg}^{-1}\right)$ is the mole amount of caffeyl alcohol (CA) per mg of $\mathrm{ChCl} / \mathrm{LA}$ lignin; $\left.\mathrm{MwCA}_{(\mathrm{mg} \mathrm{mmol}}{ }^{-1}\right)$ is the molecular weight of caffeyl alcohol (CA); $\mathrm{W}_{(\mathrm{ChCl} / \mathrm{LA} \text { lignin) }}$ is the weight percentage of $\mathrm{C}$-lignin in $\mathrm{ChCl} / \mathrm{LA}$ lignin. 


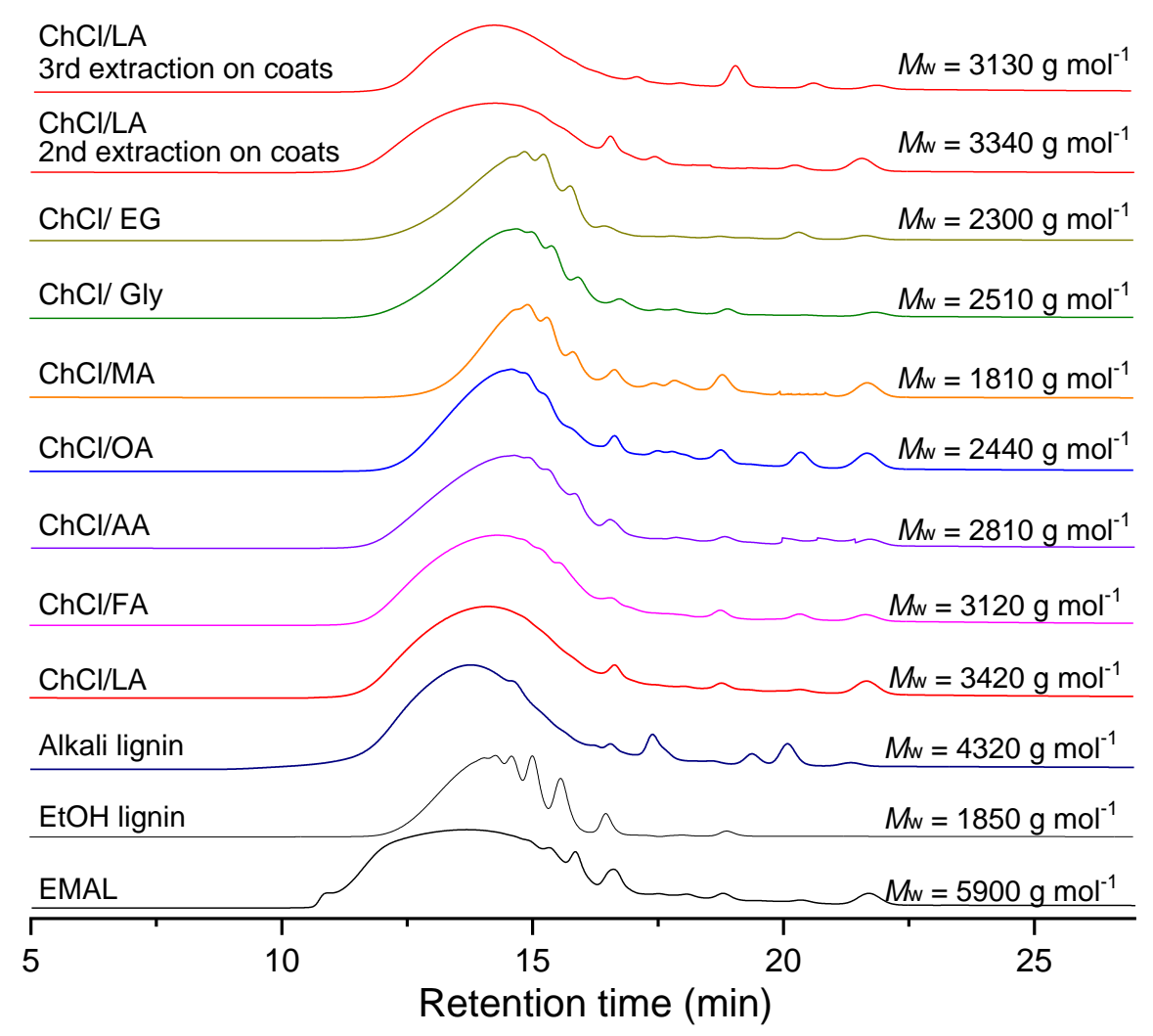

Figure S5. Molecular weight distribution of lignin samples isolated from castor seed coats by different isolation methods. 
Table S6. The distributions of lignin yield, Klason lignin contents and chemical compositional analysis of residue after $\mathrm{ChCl} / \mathrm{LA}$ DES treatment at different reaction temperatures and times. ${ }^{\text {a }}$

\begin{tabular}{cccc|cccc}
\hline & & & & & \multicolumn{3}{|c}{ Chemical component analysis of residue } \\
\cline { 5 - 7 } Entry & $\begin{array}{c}\text { Temperature } \\
\left({ }^{\circ} \mathrm{C}\right)\end{array}$ & Time (h) & $\begin{array}{c}\text { Yield of lignin } \\
(\mathrm{wt} \%)^{\mathrm{b}}\end{array}$ & $\begin{array}{c}\text { Residue } \\
(\mathrm{wt} \%)^{\mathrm{c}}\end{array}$ & $\begin{array}{c}\text { Klason } \\
\text { lignin } \\
(\mathrm{wt} \%)\end{array}$ & $\begin{array}{c}\text { Glucose } \\
(\mathrm{wt} \%)\end{array}$ & $\begin{array}{c}\text { Xylose } \\
(\mathrm{wt} \%)\end{array}$ \\
\hline 1 & 140 & 8 & 14 & 90 & 54.5 & 16.2 & 9.4 \\
2 & 140 & 16 & 28 & 80 & 51.2 & 18.6 & 10.8 \\
3 & 160 & 8 & 34 & 70 & 54.2 & 18.9 & 5.6 \\
4 & 160 & 16 & 40 & 64 & 54.6 & 22.4 & 4.7 \\
5 & 180 & 8 & 39 & 63 & 55.6 & 21.7 & 0.3 \\
7 & 180 & 16 & 43 & 57 & 56.8 & 25.2 & 0 \\
8 & 200 & 8 & 42 & 56 & 57.7 & 24.8 & 0 \\
\hline
\end{tabular}

${ }^{\mathrm{a}}$ Reaction condition: castor seed coats $(3.0 \mathrm{~g})$, DES (30.0 g); ${ }^{\mathrm{b}}$ based on the content of Klason lignin in castor seed coats; ${ }^{\mathrm{c}}$ residue was obtained after DESs treatment of castor seed coats. 

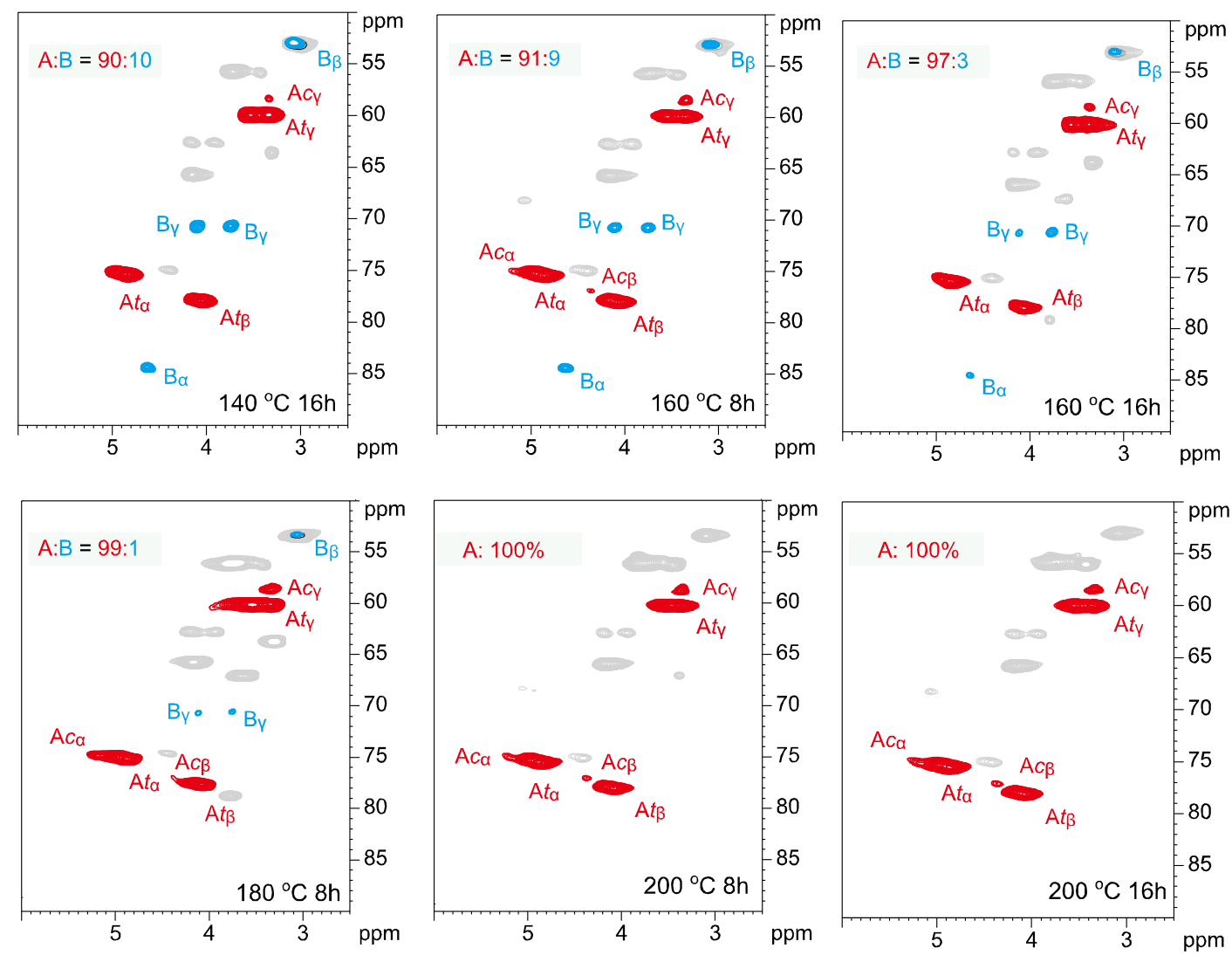

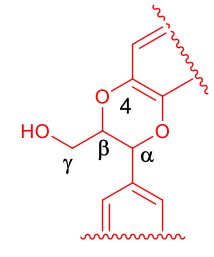

A

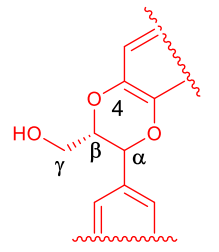

At

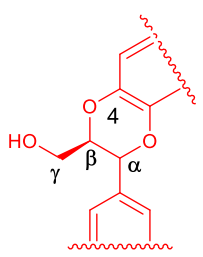

Ac

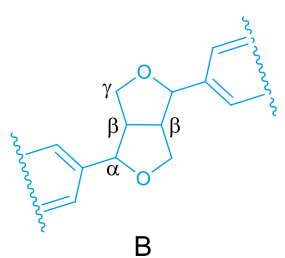

resinol

Figure S6. Expanded aliphatic side-chain regions of 2D HSQC NMR spectra of lignin samples isolated from castor seed coats by $\mathrm{ChCl} / \mathrm{LA}$ DES at different reaction temperatures and times. 

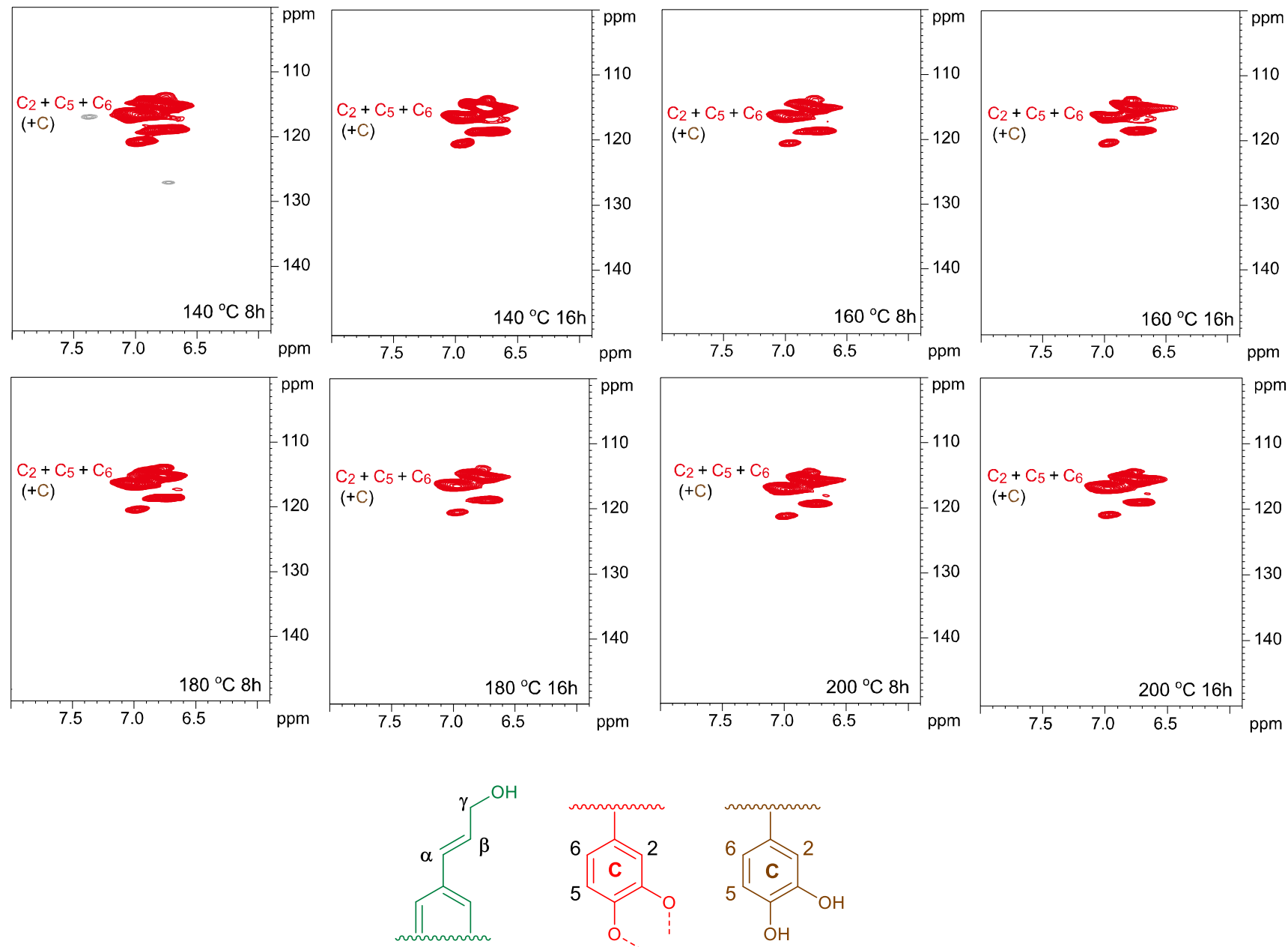

C

cinnamyl alcohol catechyl units catechyl units

$$
\text { end-units (etherified) (non-etherified) }
$$

Figure S7. Expanded aromatic regions of 2D HSQC NMR spectra of lignin samples isolated from castor seed coats by $\mathrm{ChCl} / \mathrm{LA} \mathrm{DES}$ at different reaction temperatures and times. 


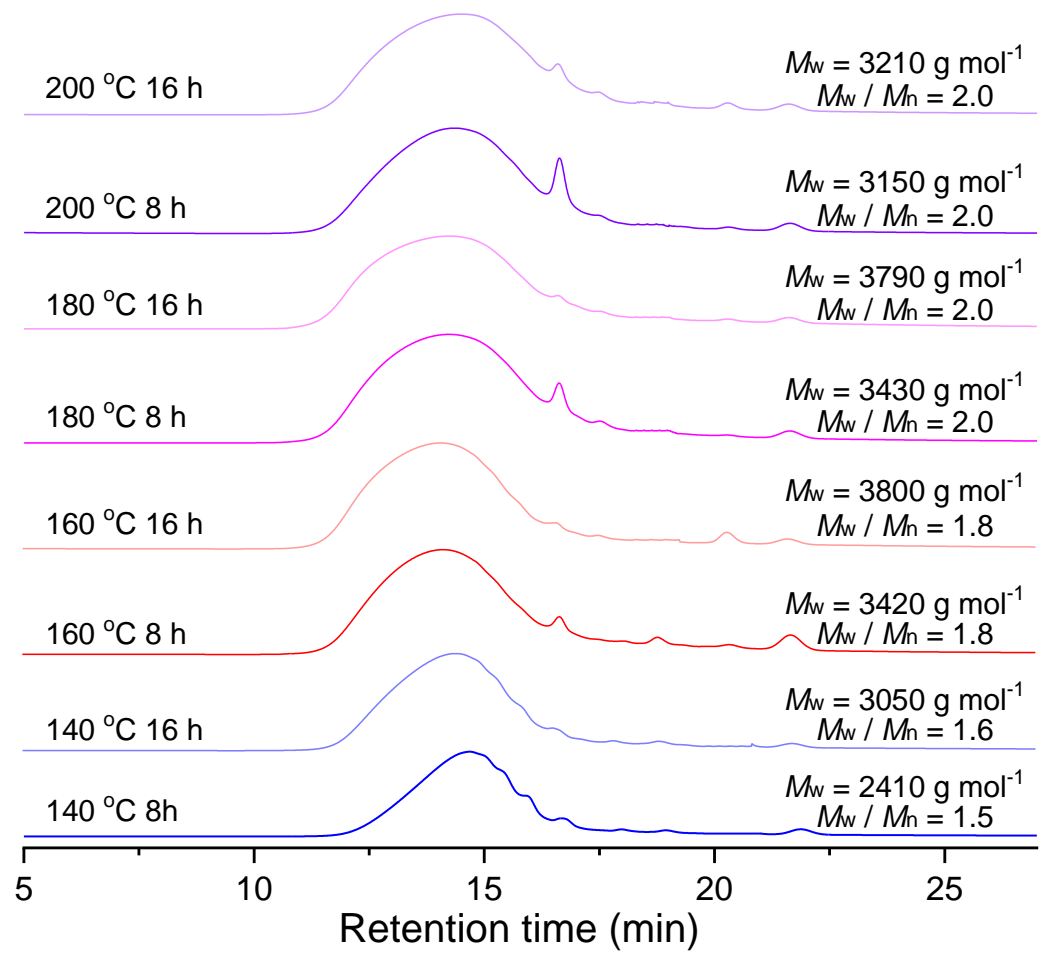

Figure S8. Molecular weight distribution of lignin samples isolated from castor seed coats by $\mathrm{ChCl} / \mathrm{LA} \mathrm{DES}$ at different reaction temperatures and times.

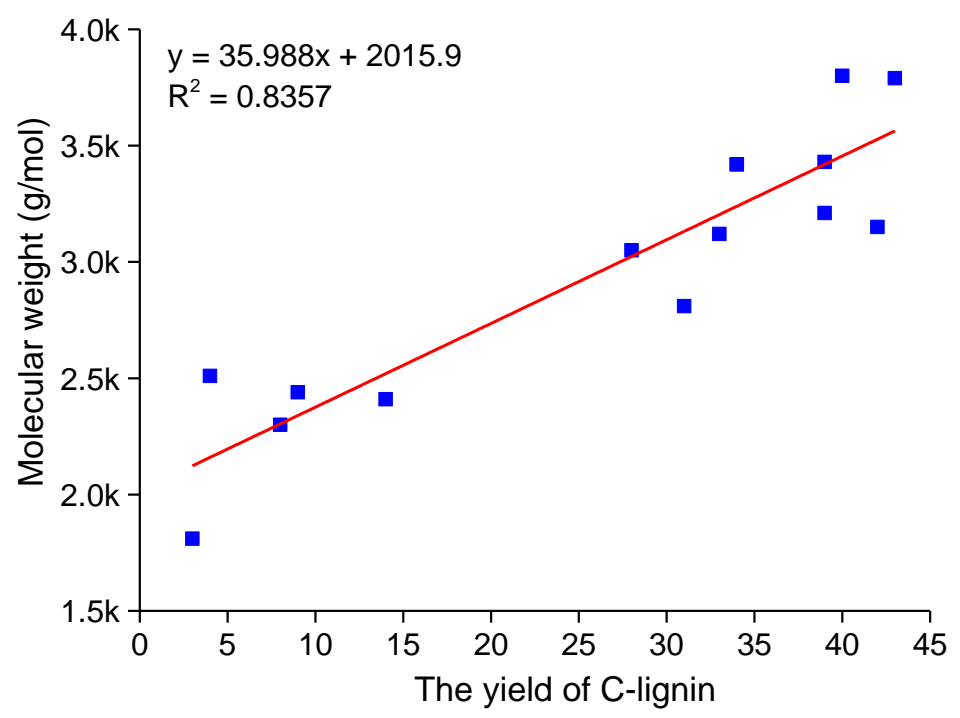

Figure S9. The relationship between yields of DESs-extracted C-lignin samples and molecular weights, in which C-lignin samples were isolated under various DESs and reaction temperatures and times. 
Table S7. The distributions of lignin yield, Klason lignin contents and chemical compositional analysis of residue after $\mathrm{ChCl} / \mathrm{LA}$ DES cycles treatment. ${ }^{\mathrm{a}}$

\begin{tabular}{cccc|cccc}
\hline \multirow{2}{*}{$\begin{array}{c}\text { Ent } \\
\text { ry }\end{array}$} & Run times & $\begin{array}{c}\text { Yield of lignin } \\
(\mathrm{wt} \%)^{\mathrm{b}}\end{array}$ & $\begin{array}{c}\text { Klason lignin } \\
(\mathrm{wt} \%)\end{array}$ & $\begin{array}{c}\text { Residue } \\
(\mathrm{wt} \%)^{\mathrm{c}}\end{array}$ & $\begin{array}{c}\text { Kalson } \\
\text { ligni } \\
(\mathrm{wt} \%)\end{array}$ & $\begin{array}{c}\text { Cellulose } \\
(\mathrm{wt} \%)\end{array}$ & $\begin{array}{c}\text { Hemicellulose } \\
(\mathrm{wt} \%)\end{array}$ \\
\hline 1 & 1 & 34 & 91 & 70 & 54.2 & 18.9 & 5.6 \\
2 & 2 & 35 & 89 & 69 & 54.1 & 20.7 & 5.8 \\
3 & 3 & 32 & 89 & 72 & 53.6 & 19.9 & 4.4 \\
4 & 4 & 31 & 94 & 74 & 53.0 & 19.0 & 7.3 \\
5 & 5 & 31 & 90 & 71 & 55.3 & 20.3 & 8.4 \\
\hline
\end{tabular}

${ }^{\mathrm{a}}$ Reaction condition: castor seed coats $(3.0 \mathrm{~g}), 160{ }^{\circ} \mathrm{C}, 8 \mathrm{~h}$; ${ }^{\mathrm{b}}$ based on the content of Klason lignin in castor seed coats; ${ }^{\mathrm{c}}$ residue was obtained after DESs treatment of castor seed coats.

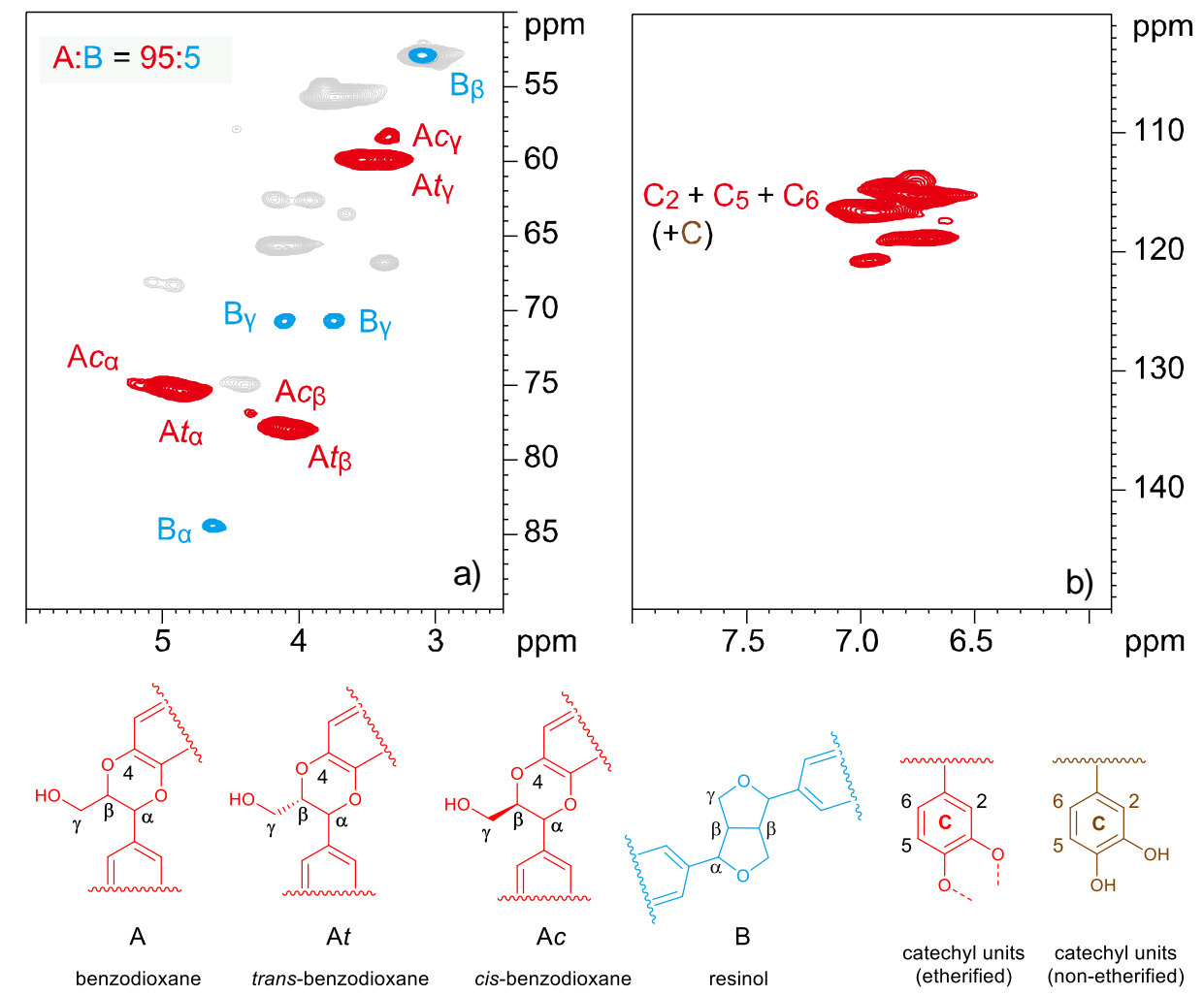

Figure S10. Expanded a) aliphatic side-chain region and b) aromatic region of 2D HSQC NMR spectra of lignin samples isolated from castor seed coats after $\mathrm{ChCl} / \mathrm{LA}$ DES cycles. 


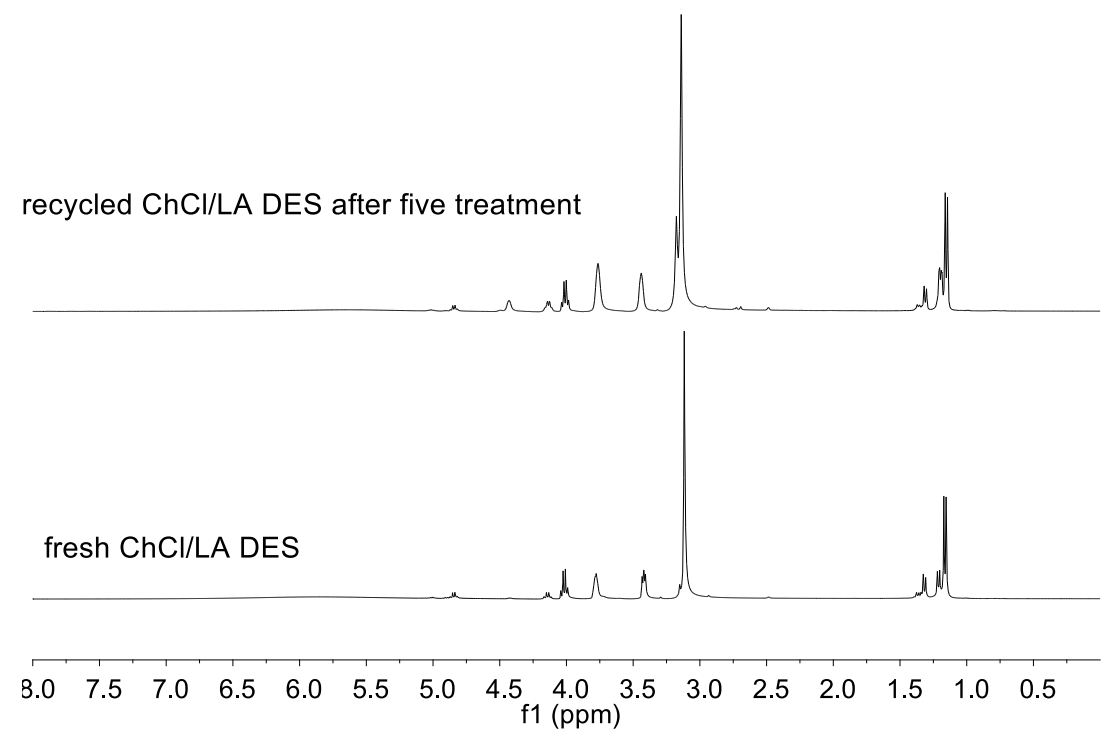

Figure S11. ${ }^{1} \mathrm{H}$ NMR spetra for fresh and recycled $\mathrm{ChCl} / \mathrm{LA}$ DES.

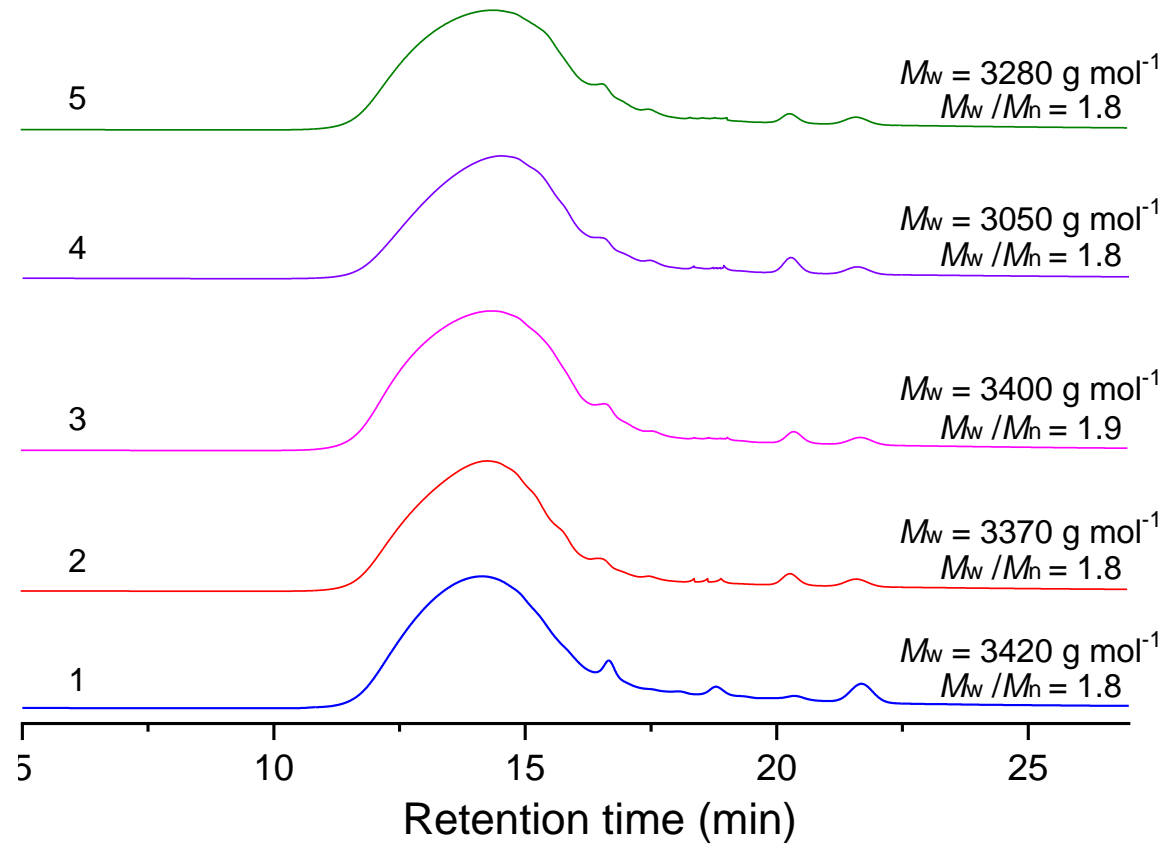

Figure S12. Molecular weight distribution of lignins isolated from castor seed coats by $\mathrm{ChCl} / \mathrm{LA}$ DES cycles. 
5. The comparison of $\mathrm{ChCl} / \mathrm{LA}$ DES and other isolated methods.

\section{Table S8}

\begin{tabular}{|c|c|c|c|c|c|}
\hline & & $\mathrm{ChCl} / \mathrm{LA}$ lignin & Kalson lignin & EMAL & EtOH lignin \\
\hline \multicolumn{2}{|c|}{ Reagents } & $\begin{array}{c}\mathrm{ChCl} / \mathrm{LA} \text { DES } \\
\mathrm{HCl}(2 \mathrm{M})\end{array}$ & $\begin{array}{c}72 \% \mathrm{H}_{2} \mathrm{SO}_{4} \\
\text { base }\end{array}$ & $\begin{array}{c}\text { Dioxane/ } \mathrm{H}_{2} \mathrm{O} \\
37 \% \mathrm{HCl} \\
\text { cellulose } \\
\text { xylanase }\end{array}$ & $\begin{array}{l}\mathrm{EtOH} / \mathrm{H}_{2} \mathrm{O} \\
98 \% \mathrm{H}_{2} \mathrm{SO}_{4} \\
\mathrm{HCl}(2 \mathrm{M})\end{array}$ \\
\hline \multicolumn{2}{|c|}{ Solid/liquid ratio } & $1: 10 \sqrt{ }$ & $1: 280$ & $1: 15$ & $1: 10 \sqrt{ }$ \\
\hline \multicolumn{2}{|c|}{ Reusability } & $\checkmark$ & $x$ & $x$ & $\sqrt{ }$ \\
\hline \multirow{3}{*}{$\begin{array}{l}\text { C-Lignin } \\
\text { properties }\end{array}$} & Yield & high & high & low & low \\
\hline & Purity (\%) & high (91) ل & low (68) & moderate (84) & moderate (81) \\
\hline & $\begin{array}{c}\text { Solubility in } \\
\text { DMSO }\end{array}$ & $\sqrt{ }$ & $x$ & $\sqrt{ }$ & $\sqrt{ }$ \\
\hline \multicolumn{2}{|c|}{ Operation process } & easy $\sqrt{ }$ & complicate & complicate & easy $\sqrt{ }$ \\
\hline \multicolumn{2}{|c|}{ Environment-friendly } & $\sqrt{ }$ & $x$ & $X$ & $\times$ \\
\hline
\end{tabular}




\section{Catalytic hydrogenolysis of castor seed coats lignin}

Catalytic experiment: In a typical reaction, lignin sample $(50 \mathrm{mg}), \mathrm{Pd} / \mathrm{C}$ or $\mathrm{Ru} / \mathrm{C}(15 \mathrm{mg}$, dried weight) and methanol $(10 \mathrm{~mL})$ were added into a $50 \mathrm{~mL}$ Parr autoclave. The reactor was sealed, purged with high purity nitrogen (99.999\%) several times, and then was pressured to desired $\mathrm{H}_{2}$ pressure $(3 \mathrm{MPa})$ at room temperature. Next, the reactor was heated to desired reaction temperature $\left(200{ }^{\circ} \mathrm{C}\right)$ with magnetic stirring $(500 \mathrm{rpm})$ for certain reaction time $(4 \mathrm{~h})$. After reaction, the autoclave was cooled and depressurized carefully. The reaction mixture was filtered, and the insoluble fraction was washed with $\mathrm{MeOH}$. Lignin oily product was obtained after removing all volatiles under vacuum condition.

An external standard (tetradecane) was added to the lignin oily solution in anhydrous tetrahydrofuran (THF), and the mixture was then treated with excess N,Obis(trimethylsilyl)trifluoroacetamide at $65{ }^{\circ} \mathrm{C}$ for $1 \mathrm{~h}$ under $\mathrm{N}_{2} \cdot{ }^{4}$ After treatment, the mixture was subjected to GC-MS and GC-FID for analysis after filtration with a PTFE filter $(0.45 \mu \mathrm{m})$. The identification and quantification of lignin monomers in the oily product were assessed by comparison with authentic samples. 
Table S9. Pd/C or Ru/C-catalyzed depolymerizaion of various lignin samples. ${ }^{\text {a }}$

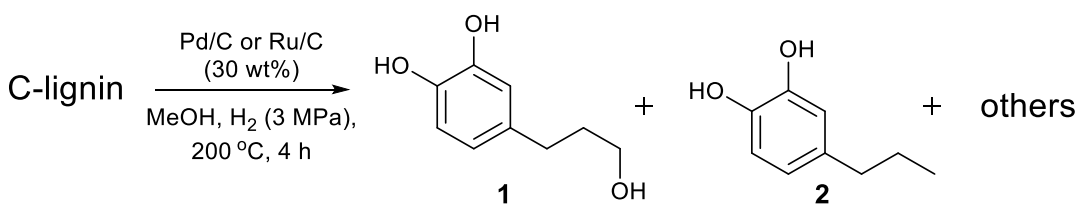

\begin{tabular}{|c|c|c|c|c|c|c|c|c|c|}
\hline \multirow{2}{*}{ Entry } & \multirow{2}{*}{ Sample } & \multirow{2}{*}{ Catalyst } & \multirow{2}{*}{$\begin{array}{l}\text { Lignin } \\
\text { oil yield } \\
(\mathrm{wt} \%)\end{array}$} & \multicolumn{3}{|c|}{ Monomer yield (wt\%) } & \multirow{2}{*}{$\begin{array}{l}\text { Selectivity for } \mathbf{1} \\
\quad(\mathrm{mol} \%)\end{array}$} & \multirow{2}{*}{$\begin{array}{c}\text { Total } \\
\text { monomers } \\
\text { yield (wt\%) }\end{array}$} & \multirow{2}{*}{$M_{\mathrm{w}}\left(\mathrm{g} \mathrm{mol}^{-1}\right)$} \\
\hline & & & & 1 & 2 & others & & & \\
\hline 1 & $\begin{array}{c}\mathrm{ChCl} / \mathrm{LA}- \\
\text { extracted lignin }\end{array}$ & $\mathrm{Ru} / \mathrm{C}$ & 65 & 10.2 & 10.9 & 1.0 & 44 & 22.1 & 560 \\
\hline 2 & $\begin{array}{c}\mathrm{ChCl} / \mathrm{LA}- \\
\text { extracted lignin }\end{array}$ & $\mathrm{Pd} / \mathrm{C}$ & 68 & 25.7 & 3.1 & 0.6 & 86 & 29.6 & 530 \\
\hline 3 & EMAL & $\mathrm{Pd} / \mathrm{C}$ & 70 & 30.0 & 1.8 & 0.4 & 93 & 32.2 & 580 \\
\hline 4 & EtOH-lignin & $\mathrm{Pd} / \mathrm{C}$ & 64 & 27.1 & 4.8 & 0.6 & 82 & 32.5 & 550 \\
\hline 5 & Alkali lignin & $\mathrm{Pd} / \mathrm{C}$ & 60 & 1.9 & 0.4 & 0.1 & 73 & 2.4 & 930 \\
\hline
\end{tabular}

${ }^{\mathrm{a}}$ Reaction condition: lignin (50 mg), Pd/C or Ru/C (metal loading: 5\%, $15 \mathrm{mg}$ ), methanol (10 mL), $\mathrm{H}_{2}(3 \mathrm{MPa}), 200{ }^{\circ} \mathrm{C}, 4 \mathrm{~h}$. 


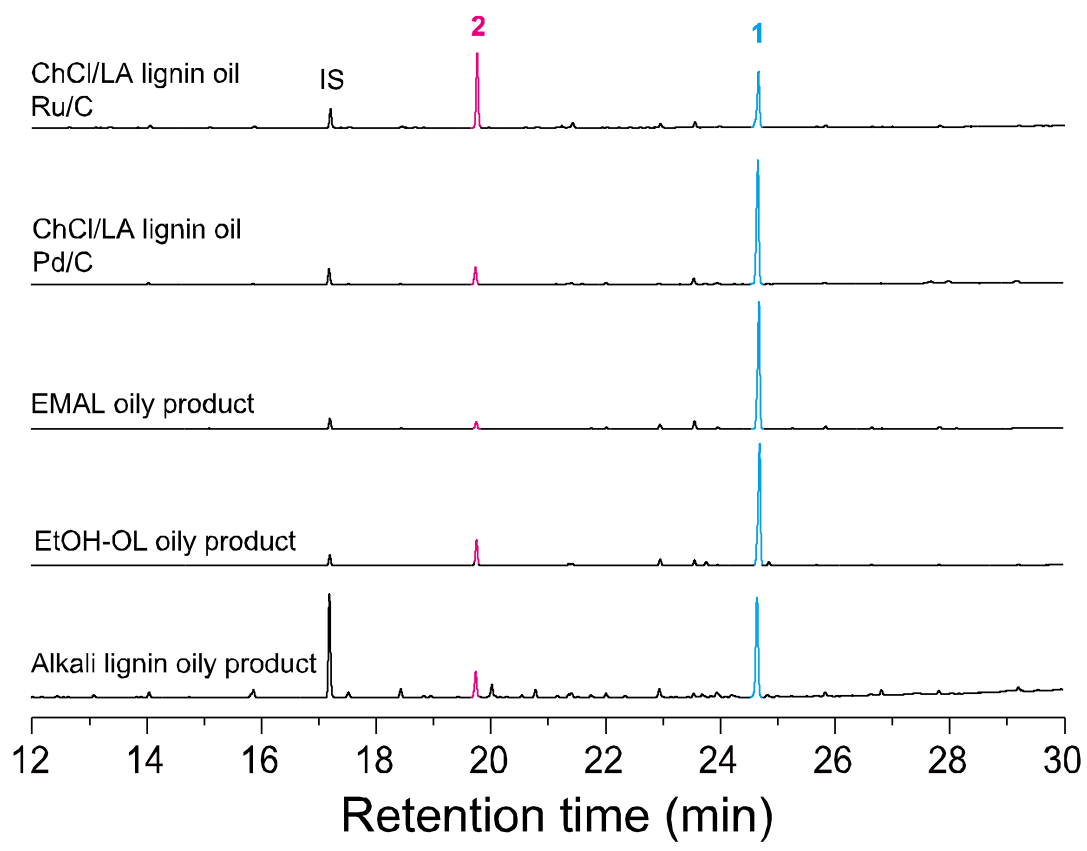

Figure S13. Gas chromatography (GC) spectra of the lignin oily products derived from the catalytic depolymerization of various lignin samples.

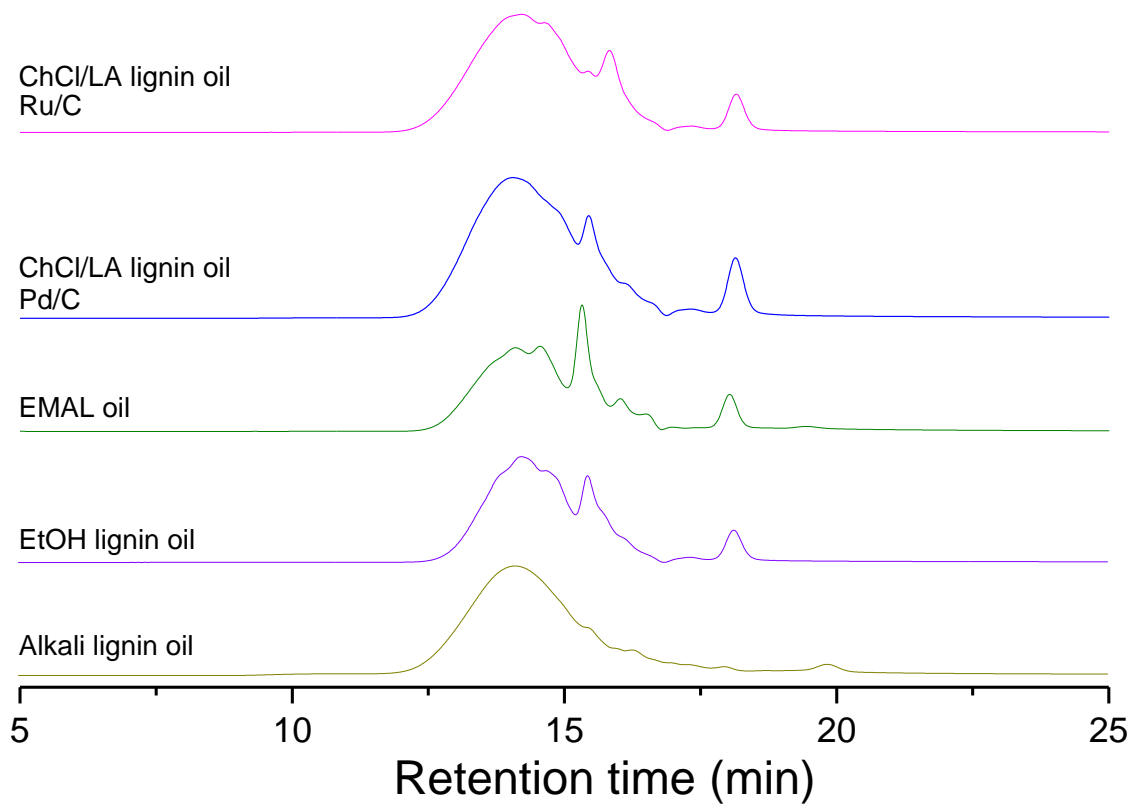

Figure S14. Molecular weight distribution of lignin oily products derived from the catalytic depolymerization of various lignin samples. 


\section{Synthesis of propanolcatechol 1 and propylcatechol 2 and their silylated derivatives}

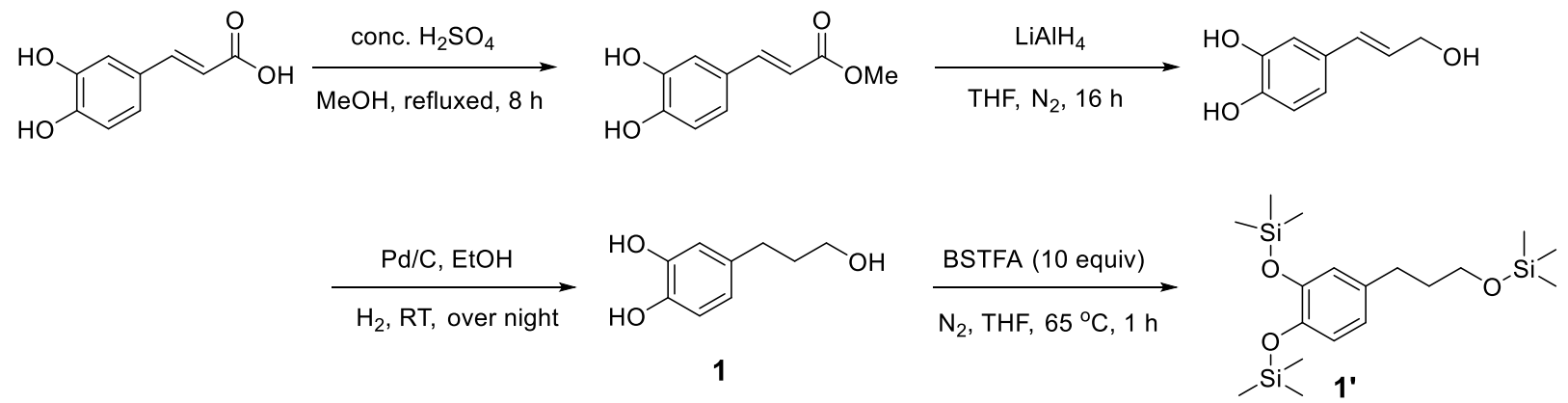

A mixture containing caffeic acid $(25 \mathrm{~g})$ and conc. $\mathrm{H}_{2} \mathrm{SO}_{4}(1.3 \mathrm{~mL})$ in $\mathrm{MeOH}(250 \mathrm{~mL})$ was refluxed at $75{ }^{\circ} \mathrm{C}$ for $8 \mathrm{~h}$. After the organic solvent was removed by rotary evaporator, the solid residue was extracted with EtOAc/water. Methyl caffeate was obtained the recrystallization of organic phase as a colorless solid (24 g, 90 \%). ${ }^{1} \mathbf{H}$ NMR (400 MHz, DMSO-d6): 9.35 (s, $\left.2 \mathrm{H}\right)$, $7.48(\mathrm{~d}, J=16.0 \mathrm{~Hz}, 1 \mathrm{H}), 7.05(\mathrm{~d}, J=2.0 \mathrm{~Hz}, 1 \mathrm{H}), 6.99(\mathrm{dd}, J=8.0 \mathrm{~Hz}, 2.0 \mathrm{~Hz}, 1 \mathrm{H}), 6.76(\mathrm{~d}, J$ $=8.0 \mathrm{~Hz}, 1 \mathrm{H}), 6.26(\mathrm{~d}, J=16.0 \mathrm{~Hz}, 1 \mathrm{H}), 3.67(\mathrm{~s}, 3 \mathrm{H}) .{ }^{13} \mathrm{C}$ NMR (100 MHz, DMSO-d6): 167.4, $148.8,146.0,145.6,125.9,121.8,116.2,115.2,114.7,51.6$.

Methyl caffeate $(500 \mathrm{mg}, 2.57 \mathrm{mmol})$ in anhydrous THF (10 mL) was added to a suspension of $\mathrm{LiAlH}_{4}\left(293.1 \mathrm{mg}, 7.72 \mathrm{mmol}, 3.0\right.$ equiv) in anhydrous $\mathrm{THF}(30 \mathrm{~mL})$ slowly at $-78{ }^{\circ} \mathrm{C}$ under $\mathrm{N}_{2}$, and the mixture was allowed to stir at RT overnight. After reaction, the mixture was quenched and acidified with $\mathrm{HCl}$ to $\mathrm{pH}=2$. $\mathrm{THF}$ was removed under low temperature by rotary evaporator and the remaining liquid was extracted with dichloromethane. The evaporation of dichloromethane and silica gel column chromatography (EA/PE) gave caffeyl alcohol as a while solid (351 mg, 82\%). ${ }^{1} \mathbf{H}$ NMR (400 MHz, CD $\left.{ }_{3} \mathrm{OD}\right): \delta 6.87(\mathrm{~d}, J=1.6 \mathrm{~Hz}, 1 \mathrm{H}), 6.73-6.67(\mathrm{~m}, 2$ H), $6.42(\mathrm{~d}, J=15.8 \mathrm{~Hz}, 1 \mathrm{H}), 6.14-6.07(\mathrm{~m}, 1 \mathrm{H}), 4.16(\mathrm{dd}, J=1.4 \mathrm{~Hz}, 6.0 \mathrm{~Hz}, 2 \mathrm{H}) .{ }^{13} \mathbf{C}$ NMR (100 MHz, $\left.\mathrm{CD}_{3} \mathrm{OD}\right): 144.9,144.6,132.8,129.2,125.2,118.4,114.8,112.5,62.5$. 
The mixture containing caffeyl alcohol $(500 \mathrm{mg}), \mathrm{Pd} / \mathrm{C}(1.0 \mathrm{~g})$ and $\mathrm{EtOH}(30 \mathrm{~mL})$ was stirred under $\mathrm{H}_{2}(1 \mathrm{~atm})$ at room temperature overnight, which underwent filtration and column chromatography (PE/EtOAc, 4:1) to afford $\mathbf{1}$ as a white solid (466 mg, 91\%). ${ }^{1} \mathbf{H}$ NMR (400 $\left.\mathrm{MHz}, \mathrm{CD}_{3} \mathrm{OD}\right): \delta 1.73-1.80(\mathrm{~m}, 2 \mathrm{H}), 2.49-2.53(\mathrm{~m}, 2 \mathrm{H}), 3.52-3.56(\mathrm{~m}, 2 \mathrm{H}), 6.50(\mathrm{dd}, J=8.0$, $2.0 \mathrm{~Hz}, 1 \mathrm{H}), 6.63(\mathrm{~d}, J=1.8 \mathrm{~Hz}, 1 \mathrm{H}), 6.76(\mathrm{~d}, J=8.0 \mathrm{~Hz}, 1 \mathrm{H}) .{ }^{13} \mathbf{C}$ NMR $\left(100 \mathrm{MHz}, \mathrm{CDCl}_{3}\right)$ : $146.3,144.5,135.8,121.7,121.3,120.8,62.1,34.3,31.5,0.49,0.30$.

The acquired compound $\mathbf{1}(100 \mathrm{mg}, 0.6 \mathrm{mmol})$ was treated with excess $\mathrm{N}, \mathrm{O}$ bis(trimethylsilyl)trifluoroacetamide $(1.55 \mathrm{~g}, 6 \mathrm{mmol})$ in anhydrous $\mathrm{THF}(10 \mathrm{~mL})$ at $65^{\circ} \mathrm{C}$ for 1 h under $\mathrm{N}_{2}$. The silylated product 1' was purified by column chromatography (PE) (87\% yield). ${ }^{1} \mathrm{H}$ NMR $\left(400 \mathrm{MHz}, \mathrm{CDCl}_{3}\right): \delta 6.75-6.72(\mathrm{~m}, 1 \mathrm{H}), 6.66-6.64(\mathrm{~m}, 2 \mathrm{H}), 3.59(\mathrm{t}, J=6.4 \mathrm{~Hz}, 2 \mathrm{H})$, $2.55(\mathrm{t}, J=7.4 \mathrm{~Hz}, 2 \mathrm{H}), 1.84-1.77(\mathrm{~m}, 2 \mathrm{H}), 0.24(\mathrm{~s}, 18 \mathrm{H}), 0.11(\mathrm{~s}, 9 \mathrm{H}) .{ }^{13} \mathrm{C}$ NMR $(100 \mathrm{MHz}$ $\left.\mathrm{CDCl}_{3}\right): 144.9,143.0,133.0,118.9,115.7,115.4,60.2,34.6,31.0$. The NMR spectra coincided with precious report in literatures. ${ }^{14}$

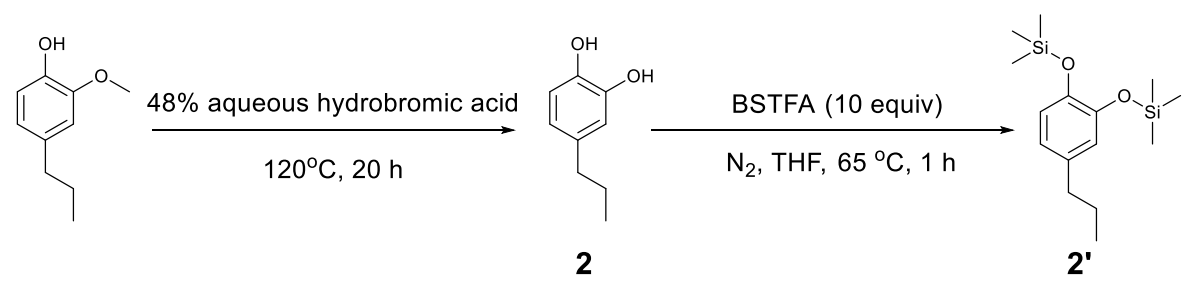

The mixture of 2-methoxy-4-propylphenol (100 mg, $0.6 \mathrm{mmol})$ and hydrobromic acid (48\% solution, $0.4 \mathrm{~mL}$ ) was stirred at $120{ }^{\circ} \mathrm{C}$ for $20 \mathrm{~h}$. After extraction with diethyl ether, the organic phase was washed with brine and dried over anhydrous $\mathrm{Na}_{2} \mathrm{SO}_{4}$. The solvent was removed via rotary evaporator and the product was purified by column chromatography (PE/EtOAc, 2:1) to yield 2 as a yellow oil $(85 \mathrm{mg}, 93 \%) .{ }^{1} \mathbf{H}$ NMR $\left(400 \mathrm{MHz}, \mathrm{C}_{6} \mathrm{D}_{6}\right): \delta 6.63(\mathrm{dd}, J=8.0 \mathrm{~Hz}, 3.6 \mathrm{~Hz}$, $1 \mathrm{H}), 6.57$ (s, $1 \mathrm{H}), 6.51$ (dd, $J=8.0 \mathrm{~Hz}, 1.8 \mathrm{~Hz}, 1 \mathrm{H}), 5.07$ (s, $2 \mathrm{H}), 2.34$ (t, $J=7.6 \mathrm{~Hz}, 2 \mathrm{H})$, 
$1.52-1.43(\mathrm{~m}, 2 \mathrm{H}), 0.83(\mathrm{t}, J=7.4 \mathrm{~Hz}, 3 \mathrm{H}) .{ }^{13} \mathbf{C ~ N M R}\left(100 \mathrm{MHz}, \mathrm{C}_{6} \mathrm{D}_{6}\right): \delta 143.7,141.6,135.5$, 120.7, 115.6, 115.3, 37.2, 24.5, 13.4.

2' was prepared through a similar method to $\mathbf{1}$ ' by using $\mathbf{2}$ as a starting material. (yield, 93\%).

${ }^{1}$ H NMR (400 MHz, $\left.\mathrm{CDCl}_{3}\right): \delta 6.74(\mathrm{~d}, J=7.8 \mathrm{~Hz}, 1 \mathrm{H}), 6.66-6.63(\mathrm{~m}, 2 \mathrm{H}), 2.50-2.46(\mathrm{~m}, 2 \mathrm{H})$, 1.65-1.56 (m, $2 \mathrm{H}), 0.95-0.91(\mathrm{~m}, 3 \mathrm{H}), 0.25(\mathrm{~d}, J=2.2 \mathrm{~Hz}, 18 \mathrm{H}) .{ }^{13} \mathbf{C} \mathbf{N M R}\left(100 \mathrm{MHz}, \mathrm{CDCl}_{3}\right)$ : $146.2,144.4,136.4,121.7,121.4,120.7,37.5,24.7,13.8,0.50$.

The NMR spectra coincided with precious report in literatures. ${ }^{15}$ 


\section{Representative GC calibration curves and GC-MS spectra, and NMR spectra $\left({ }^{1} \mathrm{H},{ }^{13} \mathrm{C}\right)$ of standard compounds}

All lignin monomers were identified by matching MS spectra and retention time to authentic standards obtained from independently synthesized.

\section{4-(3-hydroxypropyl)benzene-1,2-diol (1):}
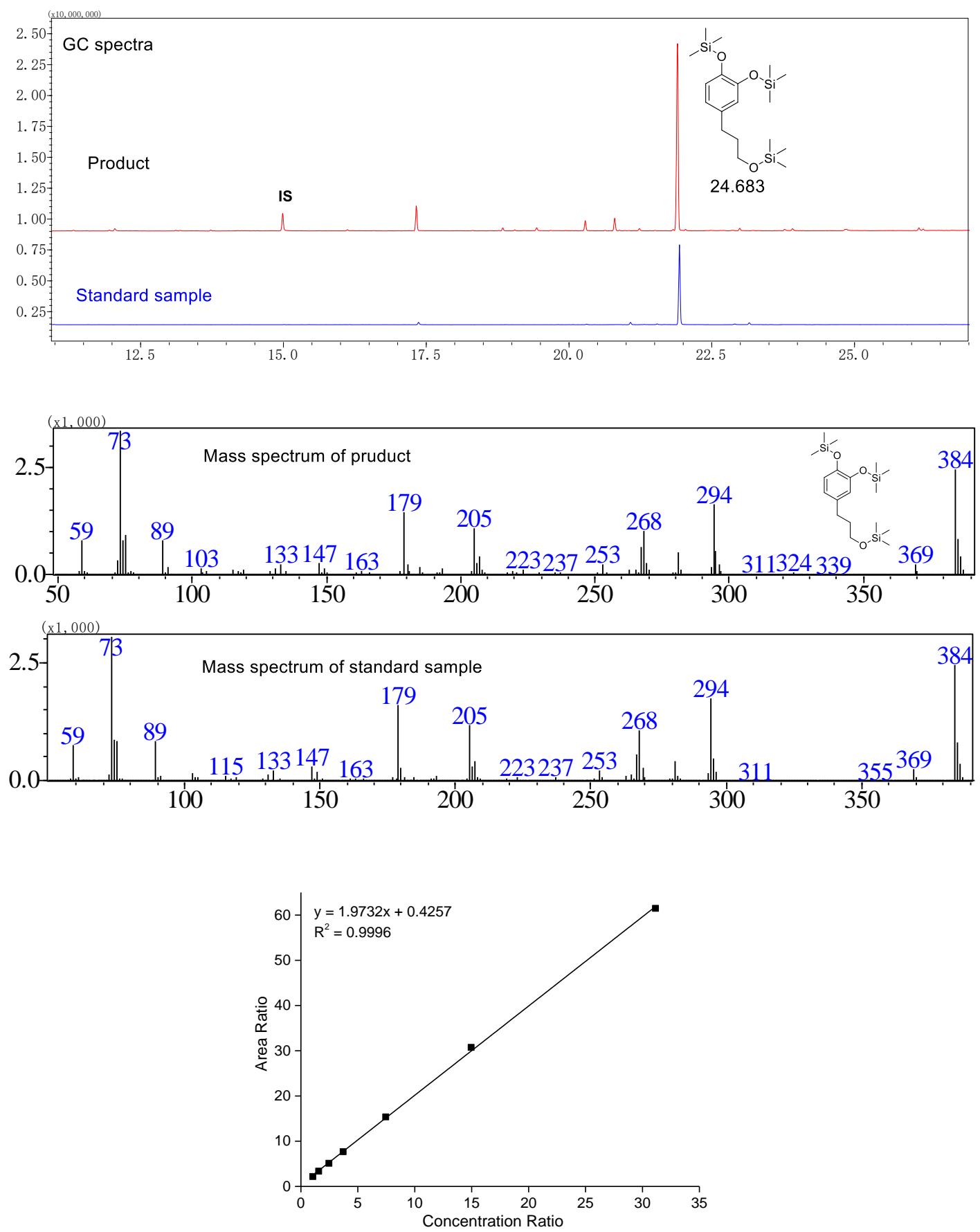


\section{4-propylcatechol (4-propylbenzene-1,2-diol, 2):}
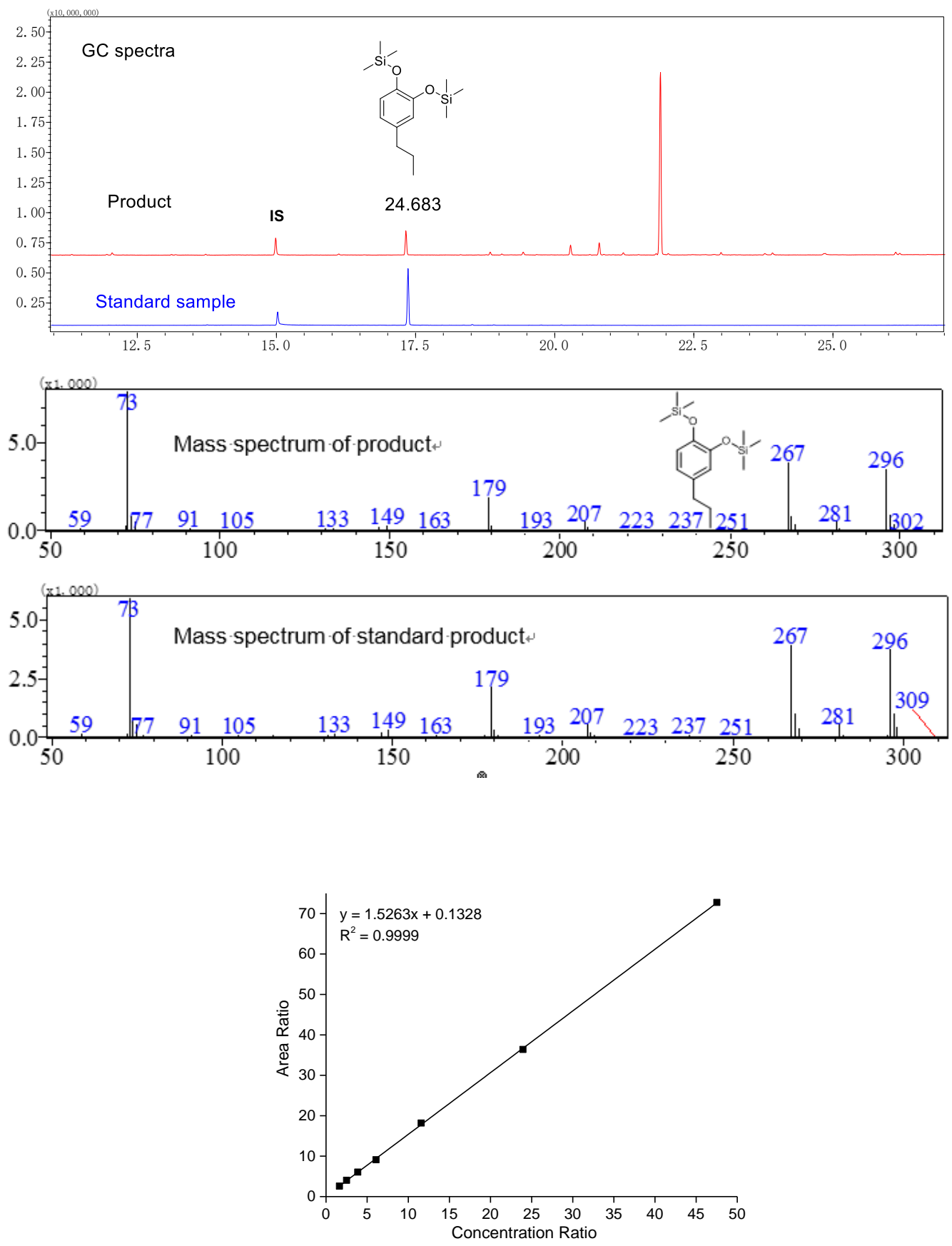

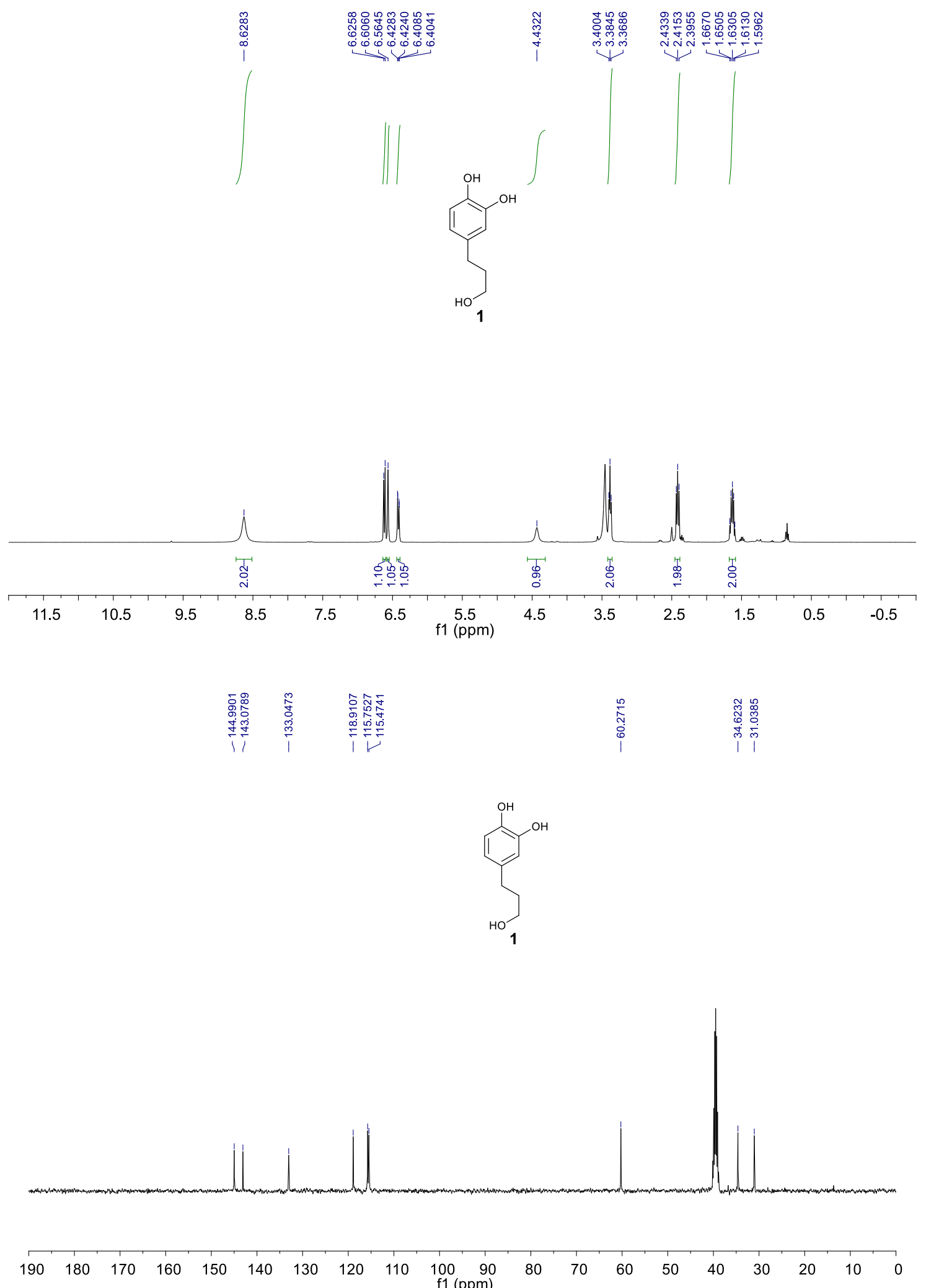


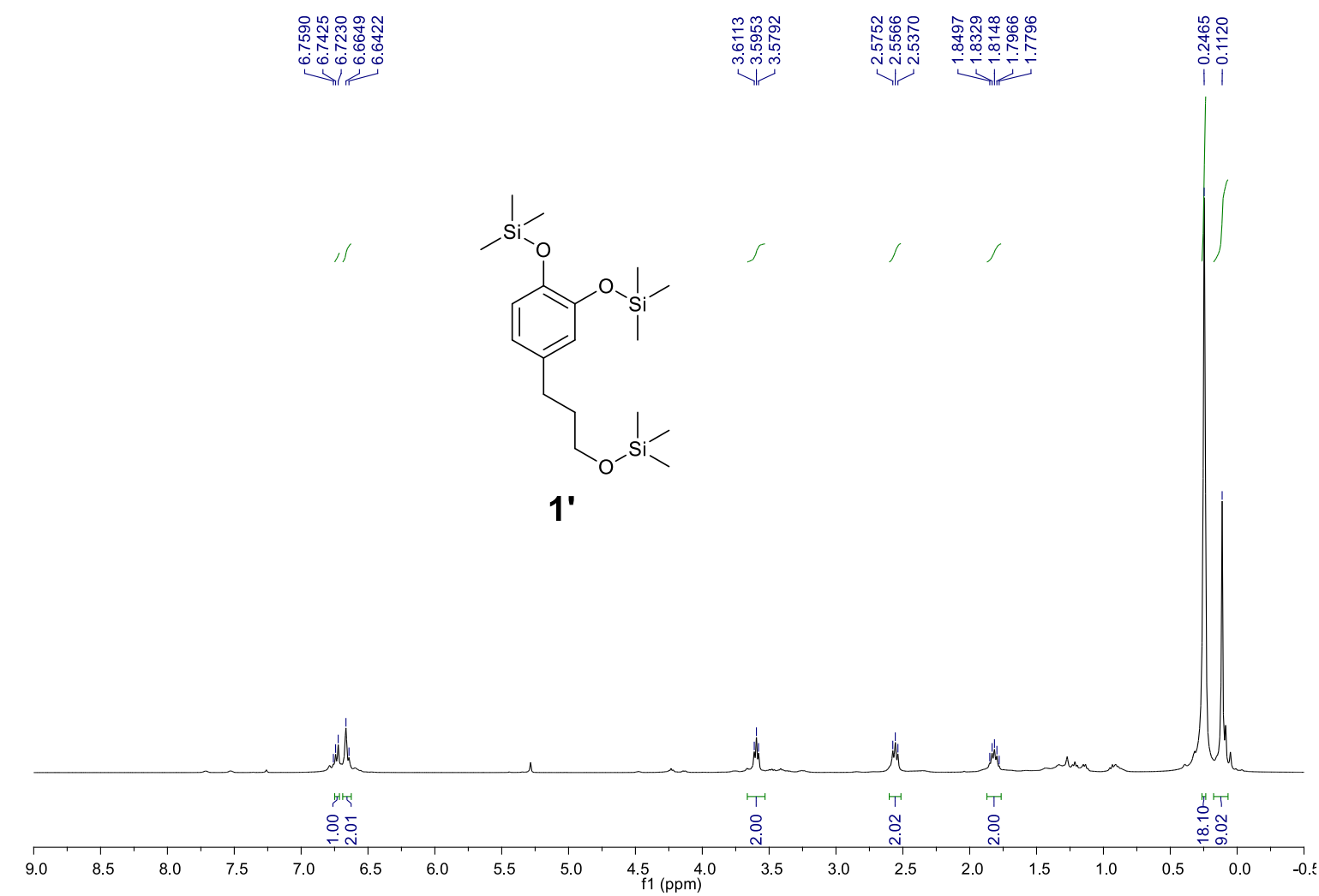

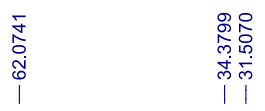

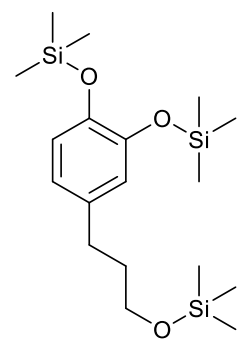

$1 '$

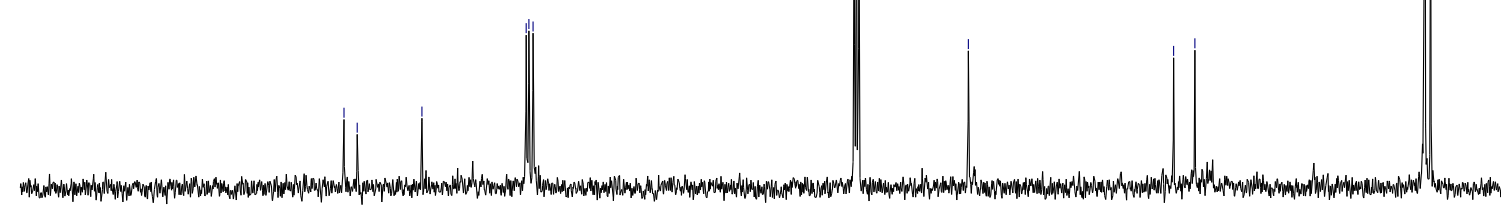

$\begin{array}{lllllllllllllllllllll}190 & 180 & 170 & 160 & 150 & 140 & 130 & 120 & 110 & 100 & 90 & 80 & 70 & 60 & 50 & 40 & 30 & 20 & 10 & 0 & -10\end{array}$ 

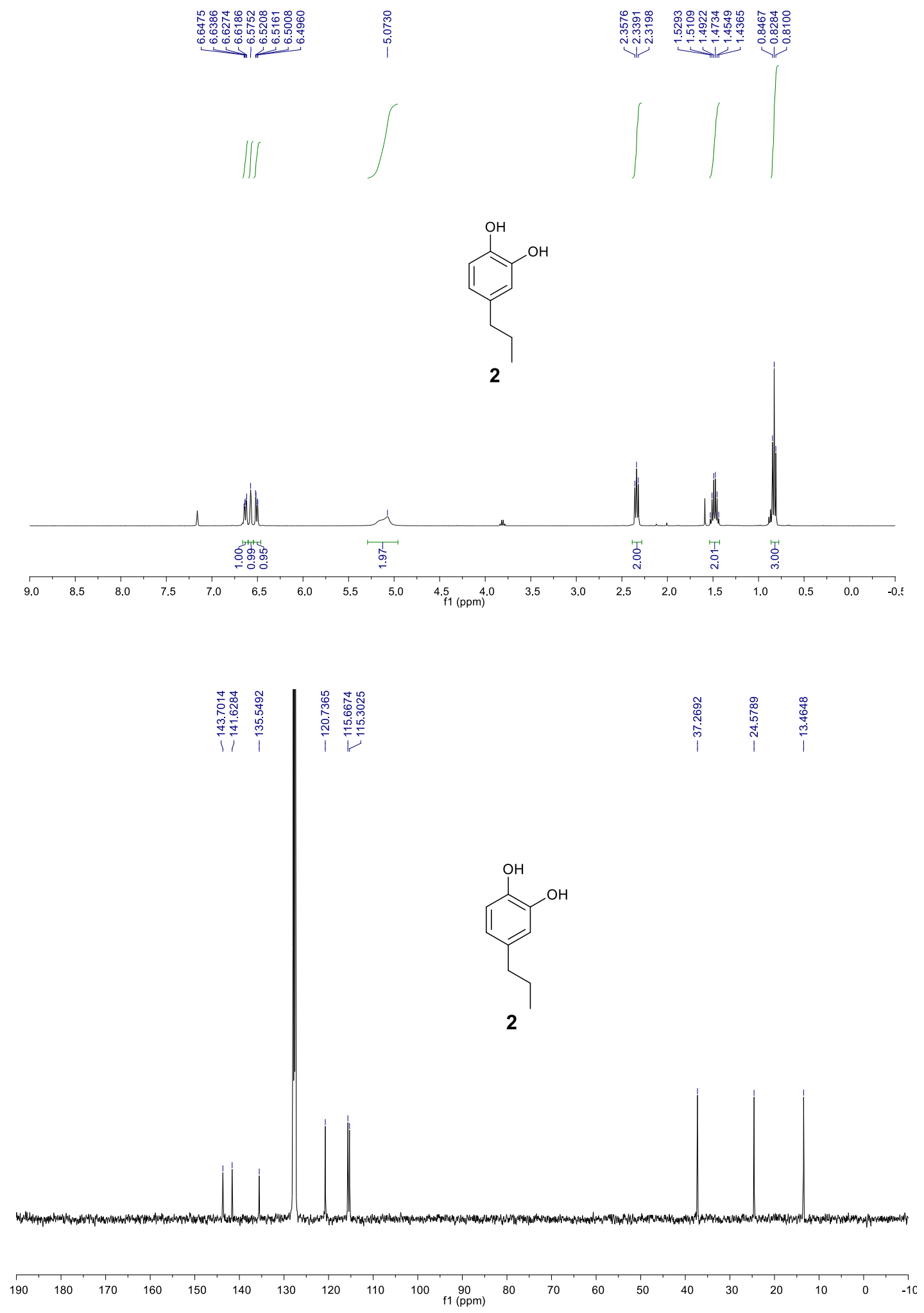


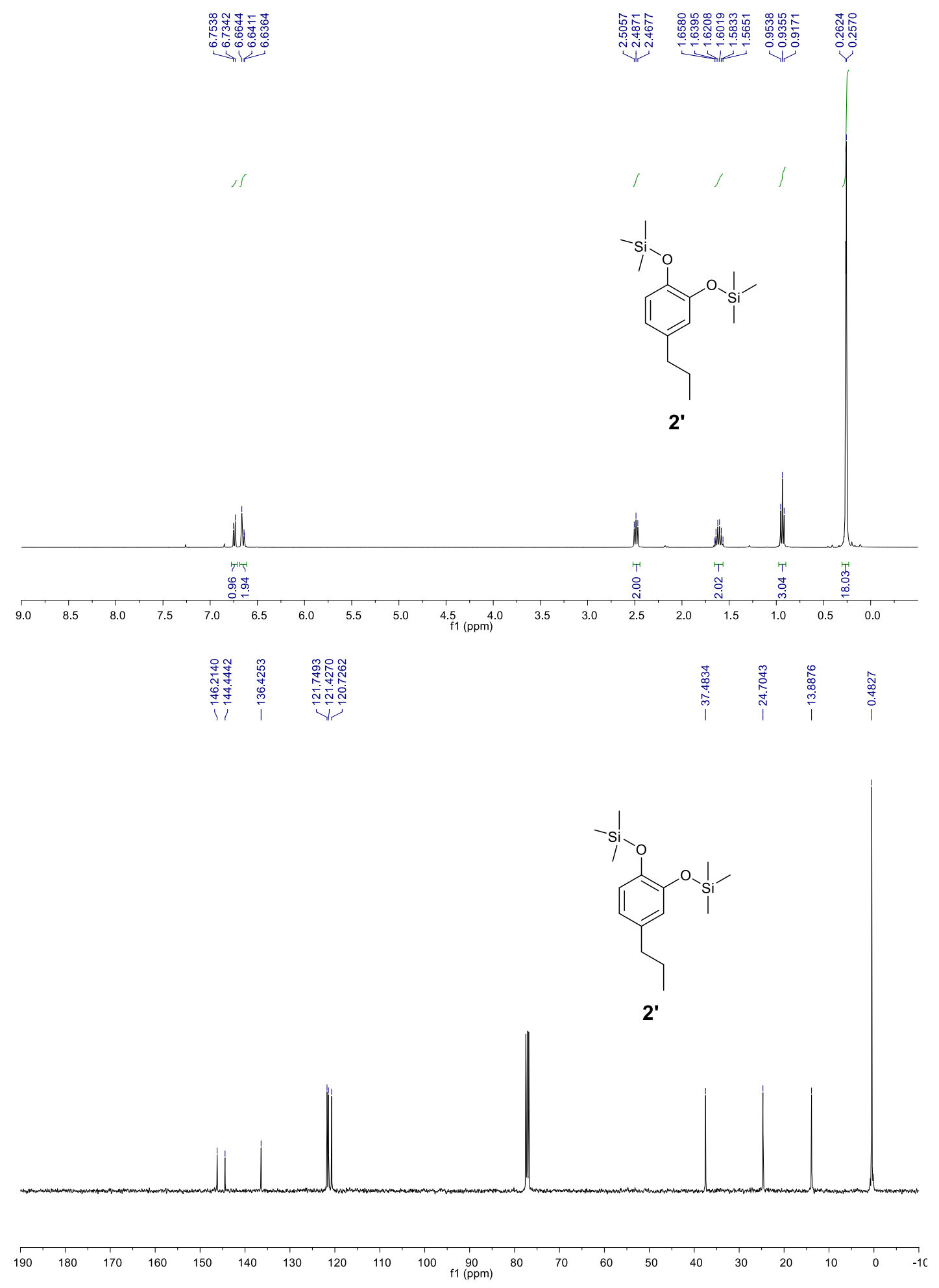




\section{References}

1. Sluiter, A.; Hames, B.; Ruiz, R.; Scarlata, C.; Sluiter, J.; Templeton, D.; Crocker, D. Determination of Structural Carbohydrates and Lignin in Biomass, National Renewable Energy Laboratory (NREL), Golden, Colorado, 2008.

2. Sluiter, A.; Hames, B.; Ruiz, R.; Scarlata, C.; Sluiter, J.; Templeton, D. Determination of Ash in Biomass, National Renewable Energy Laboratory (NREL), Golden, Colorado, 2008.

3. Li, Y.; Shuai, L.; Kim, H.; Motagamwala, A. H.; Mobley, J. K.; Yue, F.; Tobimatsu, Y.; Havkin-Frenkel, D.; Chen, F.; Dixon, R. A.; Luterbacher, J. S.; Dumesic, J. A.; Ralph, J. An "Ideal Lignin" Facilitates Full Biomass Utilization. Sci. Adv. 2018, 4, eaau2968, 1-10.

4. Gao, F.; Webb, J. D.; Hartwig, J. F. Chemo- and Regioselective Hydrogenolysis of Diaryl Ether $\mathrm{C}-\mathrm{O}$ Bonds by a Robust Heterogeneous Ni/C Catalyst: Applications to the Cleavage of Complex Lignin-Related Fragments. Angew. Chem. Int. Ed. 2016, 55, 1474-1478.

5. Alvarez-Vasco, C.; Ma, R.; Quintero, M.; Guo, M.; Geleynse, S.; Ramasamy, K. K.; Wolcott, M.; Zhang, X. Unique Low-Molecular-Weight Lignin with High Purity Extracted from Wood by Deep Eutectic Solvents (DES): A Source of Lignin for Valorization. Green Chem. 2016, 18, 5133-5141.

6. Zhang, C.-W.; Xia, S.-Q.; Ma, P.-S. Facile Pretreatment of Lignocellulosic Biomass using Deep Eutectic Solvents. Bioresour. Technol. 2016, 219, 1-5.

7. Wu, Y.; Sasaki, T.; Kazushi, K.; Seo, T.; Sakurai, K. Interactions between Spiropyrans and Room-Temperature Ionic Liquids: Photochromism and Solvatochromism. J. Phys. Chem. B 2008, 112, 7530-7536.

8. Jessop, P. G.; A. Jessop, D.; Fu, D.; Phan, L. Solvatochromic parameters for solvents of interest in green chemistry. Green Chem. 2012, 14, 1245-1259.

9. Liu, Q.; Zhao, X.; Yu, D.; Yu, H.; Zhang, Y.; Xue, Z.; Mu, T. Novel Deep Eutectic Solvents with Different Functional Groups towards Highly Efficient Dissolution of Lignin. Green Chem. 2019, 21, 5291-5297.

10. Rencoret, J.; Kim, H.; Evaristo, A. B.; Gutiérrez, A.; Ralph, J.; del Río, J. C. Variability in Lignin Composition and Structure in Cell Walls of Different Parts of Macaúba (Acrocomia aculeata) Palm Fruit. J. Agric. Food Chem. 2018, 66, 138-153.

11. Wu, S.; Argyropoulos, D. S. A Improved Method for Isolating Lignin in High Yield and Purity. J. Pulp Pap. Sci. 2003, 29, 235-240. 
12. El Hage, R.; Brosse, N.; Chrusciel, L.; Sanchez, C.; Sannigrahi, P.; Ragauskas, A. Characterization of Milled Wood Lignin and Ethanol Organosolv Lignin from Miscanthus. Polym. Degrad. Stab. 2009, 94, 1632-1638.

13. Wang H.-M.; Sun, Y.-C.; Wang, B.; Sun, D.; Shi, Q.; Zheng, L.; Wang, S.-F.; Liu, S.-J.; Xia, R.-R.; Sun, R.-C. Insights into the Structural Changes and Potentials of Lignin from Bagasse during the Integrated Delignification Process. ACS Sustainable Chem. Eng. 2019, 7, 13886-13897.

14. Sirasani, G.; Tong, L.; Balskus, E. P. A Biocompatible Alkene Hydrogenation Merges Organic Synthesis with Microbial Metabolism. Angew. Chem. Int. Ed. 2014, 53, 77857788.

15. Zhao, S.; Abu-Omar, M. M. Renewable Thermoplastics Based on Lignin-Derived Polyphenols. Macromolecules 2017, 50, 3573-358. 